\title{
Numerical experiments investigating the orographic effects on a heavy rainfall event over the northwestern coast of Taiwan during TAMEX IOP 13
}

\author{
Pay-Liam Lin • Yi-Leng Chen • Ching-Sen Chen • \\ Che-Ling Liu $\cdot$ Ching-Ying Chen
}

Received: 16 July 2011/ Accepted: 25 July 2011/Published online: 10 August 2011

(C) The Author(s) 2011. This article is published with open access at Springerlink.com

\begin{abstract}
An unusual heavy coastal rainfall event $\left(>231 \mathrm{~mm} \mathrm{day}^{-1}\right.$ ) occurred during the period of 24-25 June 1987 over the lowland (elevation less than $200 \mathrm{~m}$ ) and coastal areas in northwest and central Taiwan. The Weather Research and Forecasting (WRF) model is used to investigate the role of synoptic forcing, orographic effects and the diurnal heating cycle on the generation of a prefrontal localized low-level convergence zone offshore leading to the observed coastal rainfall maximum. This case is well simulated by the control experiment initialized at 0000 UTC (0800 LST) 24 June 1987 using the European Centre for Medium-Range Weather Forecasts data. A model sensitivity test without Taiwan's terrain fails to reproduce the observed coastal rainfall maximum. It is apparent that for this case, synoptic forcing by the Mei-Yu jet/front system is inadequate to initiate deep convection leading to the development of coastal heavy precipitation. The generation of the localized low-level convergence zone is closely related to the simulated strong winds with a large southwesterly wind component (or the barrier jet) along the northwestern coast as the surface front approaches. The development of the simulated barrier jet is due to a $50-60 \%$ increase in the meridional pressure gradient as a result of orographic blocking. The diurnal heating cycle also impacts the strength of the simulated barrier jet over
\end{abstract}

Responsible editor: M. Kaplan.

P.-L. Lin · C.-S. Chen $(\varangle)$ · C.-L. Liu · C.-Y. Chen Institute of Atmospheric Physics, National Central University, Chung-Li 320, Taiwan

e-mail: tchencs@atm.ncu.edu.tw

Y.-L. Chen

Department of Meteorology, University of Hawaii, Honolulu, Hawaii the northwestern Taiwan coast. The simulated barrier jet is stronger $\left(\sim 3 \mathrm{~m} \mathrm{~s}^{-1}\right)$ in the early morning than in the afternoon as orographic blocking is most significant when the surface air is the coldest. The representation of the terrain in the model impacts the simulated barrier jet and rainfall. With a coarse horizontal resolution $(45 \mathrm{~km})$, orographic blocking is less significant than the control run with a much weaker meridional wind component over the northwestern coast of Taiwan. The coarse resolution model fails to reproduce the observed rainband off the northwestern coast. Thus, to successfully simulate this type of event, high-resolution mesoscale models adequately depicting Taiwan's terrain are required.

\section{Introduction}

During the early summer rainy season (i.e. the Mei-Yu season from mid-May to mid-June) over Taiwan, the southwesterly monsoon flow prevails in the prefrontal atmosphere with high precipitable water and potential instability (Chen and Chen 2003). During the Mei-Yu season, under favorable environmental conditions (Chen and Li 1995a), heavy rainfall events are frequent (Yeh and Chen 1998; Li et al. 1997; Zhang et al. 2003; Chen et al. 2005, 2007a, b and others) resulting from the presence of Mei-Yu fronts, mesoscale convective systems, and localized rain showers (Chen 2000; Chen et al. 2007b). The large-scale and mesoscale environments provide favorable settings for the development of these events, whereas orographic effects and local effects determine the timing and location of their occurrence (Chen 2000).

Throughout the Mei-Yu season, heavy rainfall events occur frequently over southwestern Taiwan and the windward lower slopes of the Central Mountain Range (CMR) 
(Chen and Chen 2003; Chen et al. 2007a, b; Chen et al. 2010). During 24-25 June 1987 of the Taiwan Area Mesoscale Experiment (TAMEX, Kuo and Chen 1990), a prefrontal coastal heavy rainfall event occurred in the early morning of 25 June over the lowland (elevation less than $200 \mathrm{~m}$ ) and coastal areas in northwestern and central Taiwan (Fig. 1), associated with the last Mei-Yu jet/front system of the season (Lin et al. 1992). For this case, $\mathrm{Li}$ et al. (1997) stressed the importance of orographic effects on the development of the pre-frontal mesoscale convergence zone leading to the generation of the offshore rainband under favorable large-scale settings. They showed that this heavy rainfall event occurred in the pre-frontal

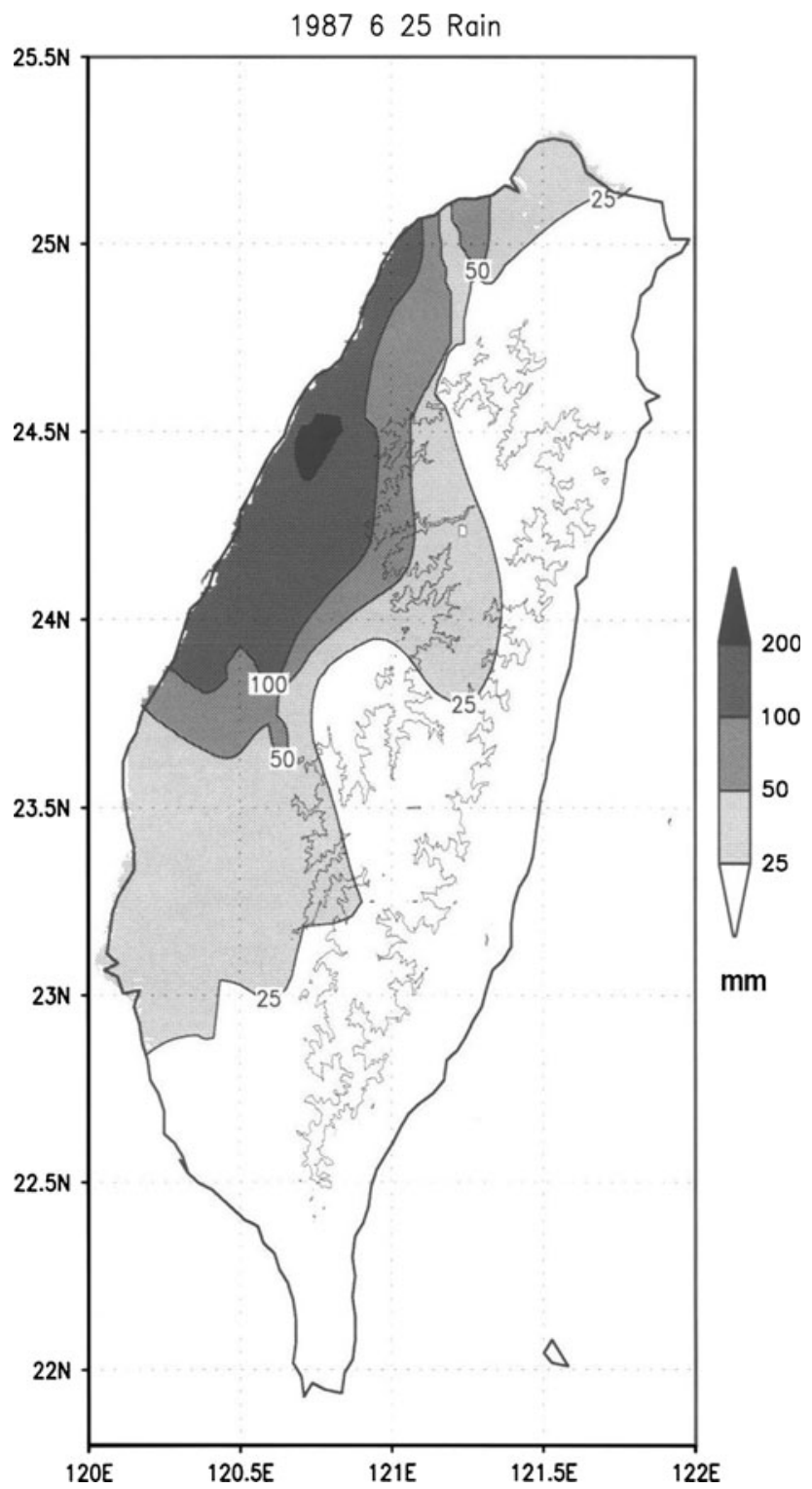

Fig. 1 The observed daily rainfall accumulation on 25 June 1987. The rainfall amount is shown by the gray scale $(\mathrm{mm})$. The $1,500-\mathrm{m}$ terrain contour (solid line) is superimposed atmosphere along the axis of maximum equivalent potential temperature at the $850-\mathrm{hPa}$ level under the presence of upper-level divergence (their Fig. 5) and large-scale rising motion. In the lower troposphere, the $850-\mathrm{hPa}$ short-wave trough associated with a deepening low over East China (their Fig. 3a) moved over the Taiwan Strait before the arrival of the weak shallow $(<1 \mathrm{~km}) \mathrm{Mei}-\mathrm{Yu}$ front, which was distorted and retarded by the $\mathrm{Wu}-\mathrm{Yi}$ mountains along the southeastern China coast (their Fig. 3b). A pre-frontal barrier jet ( $\mathrm{Li}$ and Chen 1998) forms along the northwestern coast of Taiwan due to the interaction between the sub-synoptic southwesterly monsoon flow and the island obstacle. The localized low-level convergence zone between the westerly flow behind the 850-hPa short-wave trough and the barrier jet off the northwestern Taiwan coast determines the location for the development of this longlived rainband. The barrier jet is distinctly different from the synoptic low-level jet which is a result of geostrophic adjustment processes through cross-isobar ageostrophic wind component toward lower pressure as the Mei-Yu trough deepens (Chen et al. 1994). A second, but less intense, convective period occurred during the passage of the shallow Mei-Yu front along the western coast of Taiwan a few hours later.

During the Mei-Yu season over Taiwan, the barrier jet is frequently observed along the northwestern coast of Taiwan in the prefrontal southwesterly flow ( $\mathrm{Li}$ and Chen 1998). Under a large Burger number $[B=(N / f)(h / L)](>1)$, where $h$ is the mountain height, $f$ is the Coriolis parameter, $L$ is the mountain half-width, and $N$ is the static stability, a mountain Froude number $[F r=U /(h \times N)]$, where $U$ is the wind component impinging on the mountain, can be used to characterize the appropriate hydrodynamic regime for scaling the length and magnitude of response for the region of blocked flow associated with a mountain ridge (Overland and Bond 1995). For our case, with $U \sim 10 \mathrm{~m} \mathrm{~s}^{-1}$, $h \sim 2 \mathrm{~km}, f \sim 10^{-4} \mathrm{~s}^{-1}, L \sim 50 \mathrm{~km}$, and $N \sim 10^{-2} \mathrm{~s}^{-1}$, the prefrontal southwesterly monsoon flow over Taiwan is characterized by $B \sim 4$ and $F r \sim 0.3-0.5$ (Li and Chen 1998). The initial disturbance will grow seaward to a limit given by the Rossby radius $L_{\mathrm{R}}=U / f$. The barrier jet has a maximum wind speed of $14 \mathrm{~m} \mathrm{~s}^{-1}$ at approximately $1 \mathrm{~km}$ above the surface (Li and Chen 1998). Vertical wind shear is approximately $10 \times 10^{-3} \mathrm{~s}^{-1}$ below and $4 \times 10^{-3} \mathrm{~s}^{-1}$ above the 1-km height level.

Through the observation and numerical simulation studies, Yeh and Chen (2002) found during TAMEX IOP \#3 (May 22 1987) that rainfall is enhanced over the localized convergence zone between the relatively undeflected pre-frontal southwest monsoon flow and the barrier jet under favorable large-scale conditions. To study the development of the barrier jet as a result of orographicblocking by the pre-frontal southwesterly monsoon flow, 
Table 1 Outline of all experiments

\begin{tabular}{ll}
\hline CR & Control run. The horizontal grid sizes for domains $1-4$ are $45,15,5$, and $1.67 \mathrm{~km}$, respectively \\
NT & Same as CR but without considering Taiwan topography \\
S45 & Same as CR but with only one horizontal grid spacing of $45 \mathrm{~km}$ \\
CR12 & Same as CR but with the clock reset to 12 h early \\
\hline
\end{tabular}

Yeh and Chen (2003) performed a theoretical study by initializing a mesoscale model with a single upstream sounding for the TAMEX IOP \#3. The barrier jet is well simulated with a horizontal grid spacing of $7 \mathrm{~km}$. They show that significant Lagrangian acceleration of the northern branch of the deflected airflow along the northwest coast is mainly caused by the pressure gradient force as the airflow moves down the orographically induced pressure ridge along the windward coast. The frictional retardation in low levels reduces the wind speed above the surface resulting in a vertical wind speed maximum at $\sim 800 \mathrm{~m}$.

During the 1987 Taiwan Mei-Yu season, from the principal component analysis of winds and sea-level pressure, Chen and Li (1995b) showed that the orographic blocking is the strongest in the early morning. The strength of the barrier jet is most significant in the early morning as the Mei-Yu front approaches. Recently, Chen et al. (2007b) attributed the early morning maximum occurrence of heavy rainfall over the northwestern Taiwan coast to the strengthening of offshore convergence (Yeh and Chen 2002) caused by the barrier jet. Based on rain gauge and satellite data during 1997-2002, Kerns et al. (2010) observed an early morning high cloud maximum off the northwestern coast with a coastal rainfall maximum during the Mei-Yu season. However, the axis of high cloud frequencies off the northwest coast is not a regular day-to-day occurrence. Favorable large-scale settings are also required for the development of offshore convection in the early morning. Kerns et al. (2010) attributed the observed enhanced convection in the early morning over the northwest Taiwan coast to the mesoscale convergence between the barrier jet and the environmental flow as a Mei-Yu front approaches and when the land surface is the coldest.

To quantify the relative role of synoptic pressure gradients, orographic-induced pressure gradients and land surface cooling during the occurrence of strong coastal winds (e. g., barrier jet) leading to enhanced mesoscale convergence offshore as the Mei-Yu front approaches, a high-resolution mesoscale model with full model physics is used as a research tool to study this unusual coastal heavy rainfall event. To address the impact of orographic blocking in the morning on the strength of the barrier jet, the simulated airflow and precipitation from a real case experiment with Taiwan's topography (the control run, Table 1) is compared with those from another experiment without Taiwan topography. Another model sensitivity study is performed to address the impact of the diurnal heating cycle on the strength of the barrier jet. Because the representation of orographic effects in the model also depends on grid spacing, we also conduct a model sensitivity test with a different grid size.

\section{A brief overview of the synoptic conditions and radar summary during 24-25 June 1987}

Synoptic conditions favorable for the development of convection over the northern Taiwan Strait and northern Taiwan before the commencement of heavy rainfall at 1200 UTC (LST $=$ UTC +8 h) 24 June 1987 were given by Li et al. (1997). The IR image at 2000 LST 24 June (Fig. 2a) shows the presence of deep convective clouds north of Taiwan and over southeastern China corresponding to the position of the Mei-Yu front. Note that those clouds developed in the central part of the northern Taiwan Strait near $120^{\circ} \mathrm{E}$. Three hours later (2300 LST), the Mei$\mathrm{Yu}$ front along $25^{\circ} \mathrm{N}$ extended westward to southeastern China (Lin et al. 1992). At this time, a northeast-southwest oriented cloud band was evident over the northern Taiwan Strait (Fig. 2b). By 0120 LST 25 June, the northeastsouthwest oriented radar echoes over the ocean near the northwestern coast were detected by the National Center for Atmospheric Research (NCAR) CP-4 radar near Taichung in central Taiwan ( $\mathrm{Li}$ et al. 1997). The rainband continued moving southeastward into the coastal areas of northwestern Taiwan in the early morning of 25 June (Li et al. 1997). By 0800 LST, the orientation of the rainband changed to an east-northeast-west-southwest direction from the western slope of the CMR to the adjacent ocean as the rainband moved southward (Lin et al. 1992). From 0800 to $1100 \mathrm{LST}$, intense radar echoes were observed over the lowland and coastal areas in central Taiwan (not shown), corresponding to high rainfall rates as shown in Fig. 2 of Li et al. (1997).

\section{Model description and experimental design}

In this study, the Weather Research and Forecasting (WRFv2) (Skamarock et al. 2005) model is used to assess the relative contributions of synoptic flow, orographic blocking 
(a)

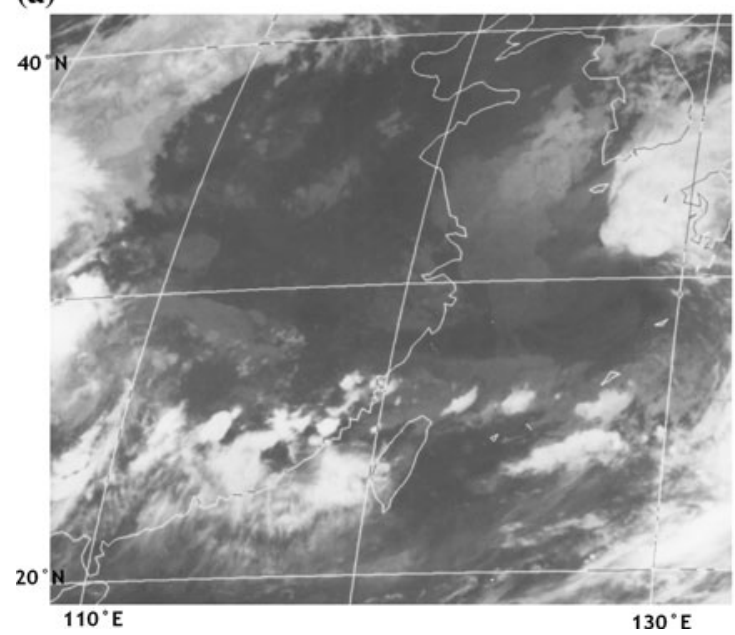

(b)

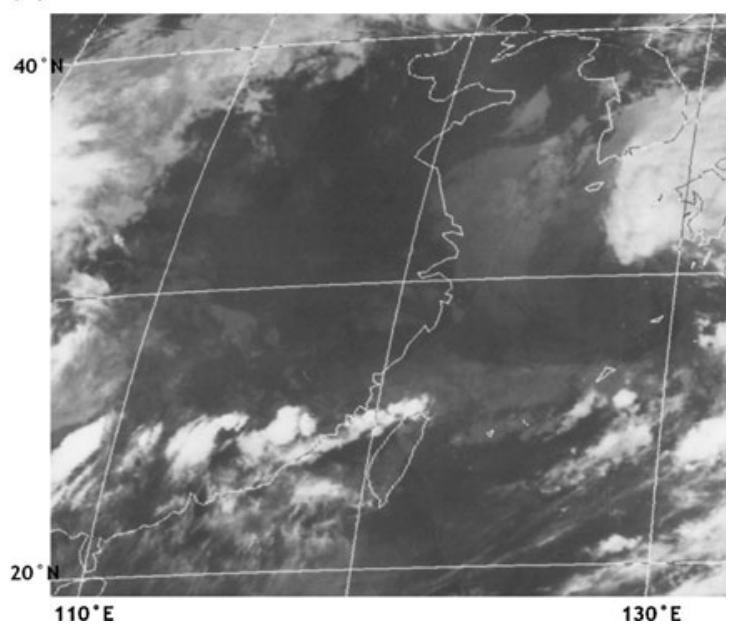

Fig. 2 a Satellite image (IR) at 2000 LST 24 June 1987. b Same as a but for 2300 LST

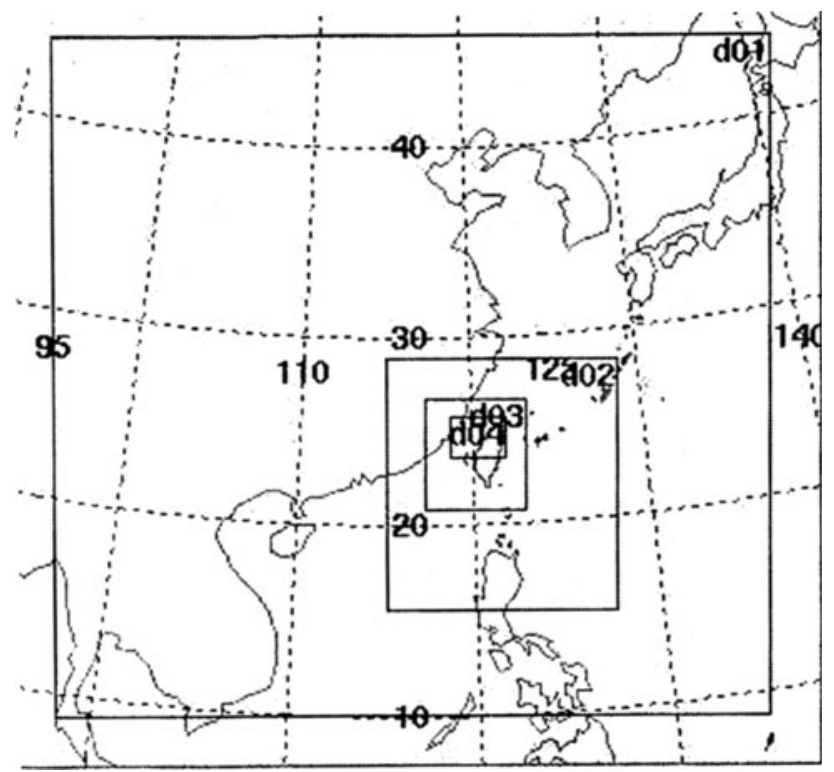

Fig. 3 The configuration of the model simulation. The horizontal grid sizes for domains $1-4$ are $45,15,5$, and $1.67 \mathrm{~km}$, respectively

and land surface forcing in the development of mesoscale convergence offshore as the Mei-Yu front approaches in the early morning. The model configuration consists of nested grids with horizontal grid spacing of $45 \mathrm{~km}$ (domain 1), $15 \mathrm{~km}$ (domain 2), $5 \mathrm{~km}$ (domain 3) and $1.67 \mathrm{~km}$ (domain 4) (Fig. 3) and 33 levels from the surface $(\sigma=1)$ to the $50-\mathrm{hPa}$ level $(\sigma=0)$.

In domain 1 and domain 2, the precipitation processes include the subgrid-scale convective parameterization of the Grell-Devenyi ensemble scheme (Grell and Devenyi 2002) and the grid-resolvable WRF single-moment 6-class microphysics scheme (WSM6) (Hong and Lim 2006), which involves prognostic equations for water vapor, cloud

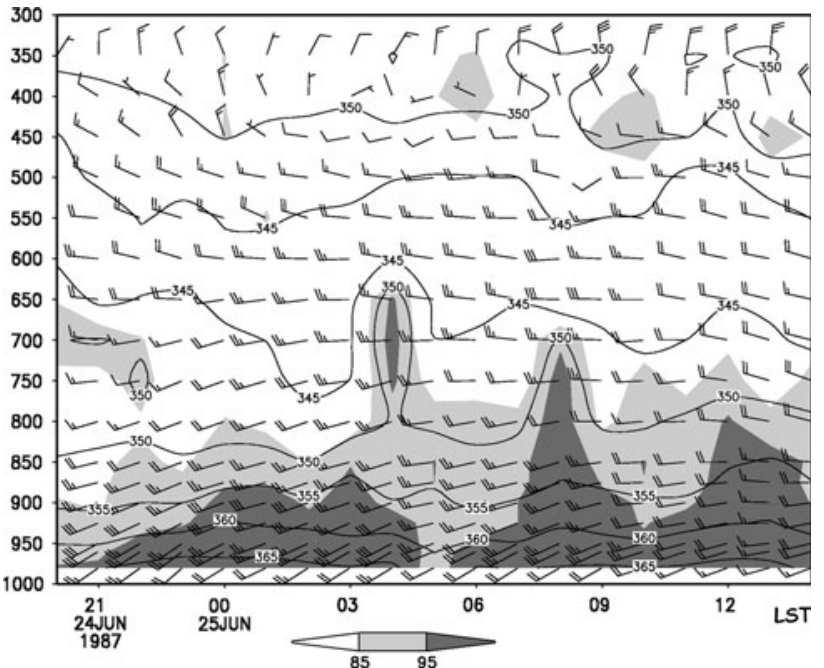

Fig. 4 Simulated temporal evolution of the vertical profiles of winds (full barb, and half barb represent 5 and $2.5 \mathrm{~m} \mathrm{~s}^{-1}$, respectively), equivalent potential temperature (solid lines, contour intervals $5 \mathrm{~K}$ ), and relative humidity (dark areas $>95 \%, 95 \%$ gray areas $>85 \%$, and white areas $<85 \%$ ) within the central Taiwan Strait (denoted by a cross near $119^{\circ} \mathrm{E}, 23.5^{\circ} \mathrm{N}$ in Fig. 5a) from 20 LST 24 June to 14 LST 25 June 1987 from the 5-km grid domain

water, rainwater, cloud ice, snow, and graupel. In the 5-km and $1.67-\mathrm{km}$ domains, the convective parameterization scheme is turned off. The Yonsei University PBL parameterization (Hong et al. 2006) is used to represent planetary boundary layer processes. The land surface model has five soil layers (Dudhia 1996). The longwave and shortwave radiation schemes employ the rapid radiative transfer model (RRTM) (Mlawer et al. 1997) and Dudhia scheme (Dudhia 1989), respectively.

For the control run (CR, Table 1), the WRF model is initialized at 0000 UTC (0800 LST) 24 June 1987 using the global analysis from the European Centre for Medium- 


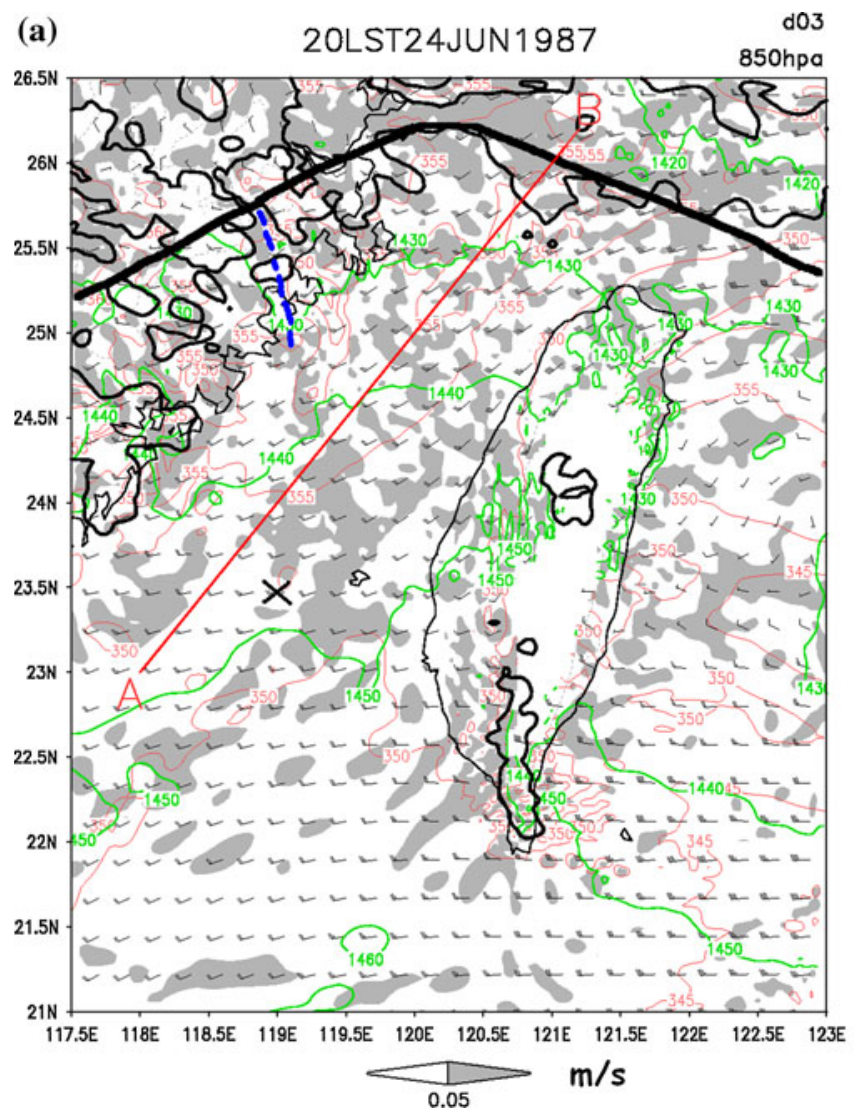

Fig. 5 a Simulated geopotential heights (green solid lines, $10 \mathrm{gpm}$ contour interval), horizontal winds (full barb, and half barb represent 5 and $2.5 \mathrm{~m} \mathrm{~s}^{-1}$, respectively), upward motions (dark areas $>0.05 \mathrm{~m} \mathrm{~s}^{-1}$ ), equivalent potential temperature (red solid lines, $5 \mathrm{~K}$ contour interval) and rainfall rate exceeding $1 \mathrm{~mm} \mathrm{~h}^{-1}$ (dark solid lines) at the 850-hPa level from the 5-km grid domain for 2000 LST 24 June 1987. The heavy solid line represents the position of the Mei$\mathrm{Yu}$ front determined from surface winds. A wind-shear line over the

Range Weather Forecasts. In the CR run, a barrier jet associated with Taiwan's topography and the subsequent development of a rainband are reproduced. A run similar to the CR run, but without Taiwan's topography, is performed (NT, Table 1) to examine whether or not the rainband and heavy rainfall would be able to develop under favorable large-scale settings without orographic blocking. To test the hypothesis that the orographically induced pressure gradients in the early morning play an important role for the development of low-level strong coastal winds, the force balance in the meridional momentum equation is evaluated from the model output of the CR run and compared with that from the NT run. In addition, to study the impact of the diurnal heating cycle on the strength of the barrier jet, another model sensitivity test (CR12, Table 1) is performed. The CR12 run is similar to the CR run but has the clock reset to $12 \mathrm{~h}$ early. In other words, the initial and lateral boundary conditions for 2000 LST 23 June and 0200 LST 24 June in the CR12 run are identical to 0800 (b) 2OLST24JUN1987

d03

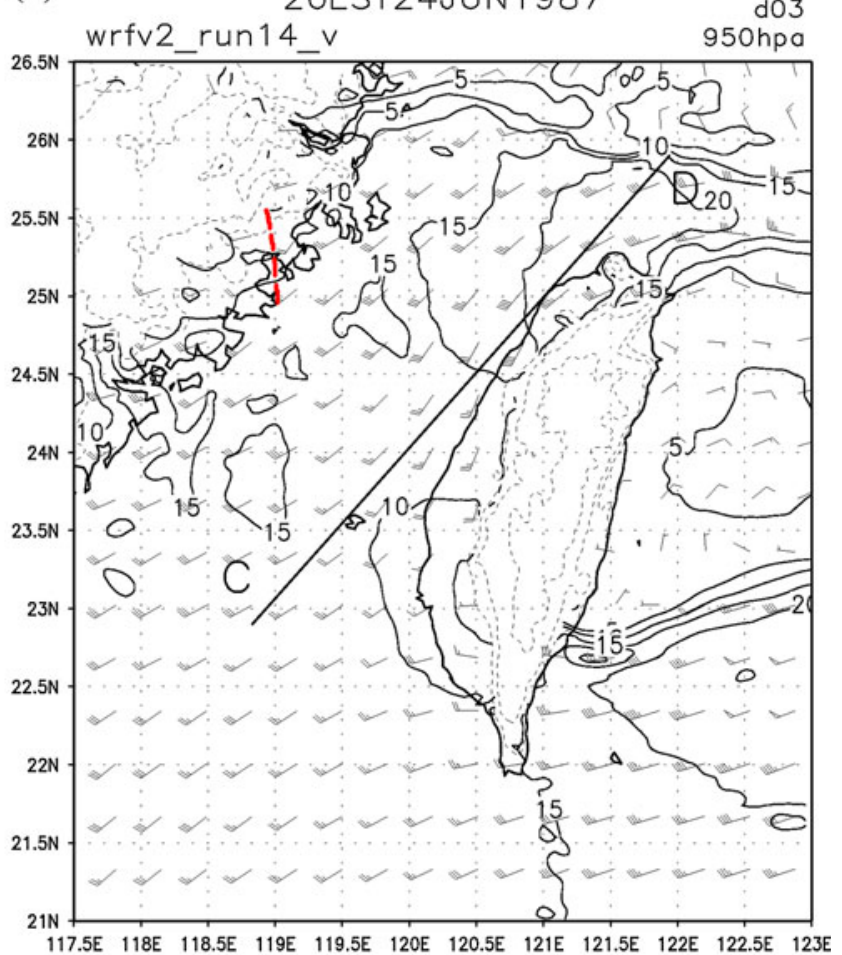

southeastern China coast is depicted by a blue dashed line. b Simulated horizontal winds (full barb, and half barb represent 5 and $2.5 \mathrm{~m} \mathrm{~s}^{-1}$, respectively) and wind speed (solid line in $\mathrm{m} \mathrm{s}^{-1}$ ) at the $950-\mathrm{hPa}$ level from the 5-km grid domain for 2000 LST 24 June 1987. The terrain elevation (dashed lines) is 200,500 , and $1,500 \mathrm{~m}$, respectively. A wind-shear line over the southeastern China coast is depicted by a red dashed line

LST and 1400 LST 24 June in the CR run. To evaluate the impact of he representation of orographic effects in the model with a different horizontal resolution on the strength of the barrier jet, a model sensitivity test (S45) is also performed (Table 1) with a $45-\mathrm{km}$ grid spacing.

\section{Simulation results}

\subsection{The control run}

The temporal evolution of simulated winds, equivalent potential temperature $\left(\Theta_{\mathrm{e}}\right)$, and relative humidity profiles within the central Taiwan Strait near $119^{\circ} \mathrm{E}, 23.5^{\circ} \mathrm{N}$ from the 5-km grid simulation is given in Fig. 4. At 1200 UTC (2000 LST) 24 June 1987, the southwesterly monsoon flow is potentially unstable. In the evening of 24 June, the relative humidity and equivalent potential temperature increase in the lower troposphere under the southwesterly 
flow providing a favorable environment for triggering heavy rainfall (Fig. 4).

The horizontal distributions of $850-\mathrm{hPa}$ geopotential height, winds, $\Theta_{\mathrm{e}}$, and ascending motions over the Taiwan area from the results of the $5-\mathrm{km}$ grid simulation valid at 2000 LST 24 June are shown in Fig. 5a. A short-wave trough/wind- shear line is simulated over the southeast China coast with a west-southwesterly (southwesterly) wind over the sameregion (the northern Taiwan Strait). This wind-shear line also appears at the 950-hPa level (Fig. 5b). In Fig. 5b, over the northwestern coast of Taiwan, the southwesterly flow with wind speeds exceeding $15 \mathrm{~m} \mathrm{~s}^{-1}$ (barrier jet), extends about $100 \mathrm{~km}$ off the coast (also shown in Fig. 5a) consistent with the estimated Rossby radius (Li and Chen 1998). During this time period, the simulated surface front (determined by the change of the surface wind direction) is north of Taiwan with rainfall extending from the ocean to the southeastern China coast (Fig. 5a), consistent with satellite imagery (Fig. 2a). Ascending motions with high $\Theta_{\mathrm{e}}$ are simulated in the central part of the northern Taiwan Strait. Along the cross section $\mathrm{AB}$ (Fig. 5a), it is apparent that the moist, high $\Theta_{\mathrm{e}}$ air near $120^{\circ} \mathrm{E}$ and $25^{\circ} \mathrm{N}$ is lifted by the ascending motions (Fig. 6a) with moist tongues (relative humidity $>90 \%$ ) extending well above the level of free convection (LFC) [near $2.2 \mathrm{~km}(\sim 780 \mathrm{hPa})$ ] (Lin et al. 1992). Along the same cross section, the ascending motions associated with the Mei-Yu front are located further north near $121^{\circ} \mathrm{E}$ and $25.9^{\circ} \mathrm{N}$ (Figs. 5a and 6a). Off the northwestern coast of Taiwan (Figs. 5a and 5b), a barrier jet (Li and Chen 1998; Li et al. 1997) is simulated with splitting airflow over southwestern Taiwan. A northeast-southwest cross section passing through the northwest coast (Line CD in Fig. 5b) indicates that the low-level wind component along Line CD increases from the southwestern Taiwan coast to the northwestern coast (Fig. 6b) with a wind speed maximum $\sim 16.5 \mathrm{~m} \mathrm{~s}^{-1}$ (or the barrier jet) near the 950-hPa level ( $\sim 0.6 \mathrm{~km}$ above the surface) off the northwestern coast ( $\sim 121.25^{\circ} \mathrm{E}$ ), in good agreement with observations ( $\mathrm{Li}$ and Chen 1998; Li et al. 1997).

At 0200 LST 25 June, the wind-shear line and the westsouthwesterly flow behind it migrate eastward toward the northwestern coast (Fig. 7). The convergence zone between the west-southwesterly wind and the barrier jet also moves eastward toward the northwestern Taiwan coast (Fig. 7). In conjunction with the eastward movement of the convergence area, the simulated rainband moves onshore (Fig. 7). In the mean time, the simulated Mei-Yu front arrives over the northern Taiwan Strait, in agreement with radar observations ( $\mathrm{Li}$ et al. 1997, their Fig. 2). At 0800 LST, most of the prefrontal convective activities move inland over central Taiwan (not shown).
The 1.67-km grid simulation for 25 June (Fig. 8a) shows that the simulated daily maximum rainfall is over the northwestern coast of Taiwan before the Mei-Yu front arrived. This is consistent with the observations (Fig. 1), except the accumulated rainfall in the model overestimates rainfall amount over the mountainous area $(\sim 125 \mathrm{~mm}$ day ${ }^{-1}$ ) where rainfall stations are sparse (Fig. 8a). The higher than observed simulated rainfall over mountainous areas is also found in Yeh and Chen's (2002) study of the TAMEX IOP 3 case using the MM5 model.

\subsection{The mechanisms for the production of the barrier jet}

As the maximum wind speed of the simulated barrier jet over the northwest coast of Taiwan (Fig. 6b) at 2000 LST 24 June in the control run is near the 950-hPa level (or $\sigma=0.933$ ), the discussion on the generation mechanism of the barrier jet will be at $\sigma=0.933$. The meridional (Fig. 9a) and u-wind components (Fig. 9b) at 2000 LST 24 June from the $\mathrm{CR}$ run indicate that the southerly wind increases from the southwestern coast of Taiwan $\left(\sim 120^{\circ} \mathrm{E}\right.$ and $\left.23.5^{\circ} \mathrm{N}\right)$ to the northwestern coast $\left(\sim 121^{\circ} \mathrm{E}\right.$ and $\left.24.9^{\circ} \mathrm{N}\right)$. Therefore, the force balance of the meridional momentum equation (Skamarock et al. 2005) (Appendix) is studied from the model output. The Lagrangian acceleration of the meridional wind (including the local change and the advection terms) shown in Fig. 9a is closely related to the pressure gradient force term (Fig. 9c). The pressure gradient force is contributed by the pressure associated with a hydrostatically balanced reference state and a perturbation pressure deviated from this reference state. To the south and west of the maximum meridional wind, significant positive Lagrangian acceleration and a large positive pressure gradient force exist. To the north of the maximum meridional wind, significant Lagrangian deceleration and a negative pressure gradient force occur. Furthermore, the decrease of the perturbation pressure from the coastal area of southwestern Taiwan to the northwestern coast of Taiwan at the 950-hPa level is about $1.8 \mathrm{hPa}$ (Fig. 9c). The perturbation pressure contours tighten over the northwestern coast (near $24.6^{\circ} \mathrm{N}$ and between $120.6^{\circ} \mathrm{E}$ and $120.8^{\circ} \mathrm{E}$ ) (Fig. 9c) west of the maximum meridional wind, resulting in a significant increase of Lagrangian acceleration over the northwestern coast (Fig. 9a). The Coriolis force decelerates the meridional wind over western and northwestern Taiwan (Fig. 9d). The mixing term (Fig. 9e, including the subgridscale eddy fluxes, numerical smoothing, and truncation errors in the model), calculated as the residual from the meridional momentum equation, is very small, about three orders of magnitude smaller than the pressure gradient force. Thus, the pressure gradient force is the most 
Fig. 6 a Simulated winds (full barb, and half barb represent 5 and $2.5 \mathrm{~m} \mathrm{~s}^{-1}$, respectively), upward motions (shaded areas $>0.02 \mathrm{~m} \mathrm{~s}^{-1}$ ), equivalent potential temperature (solid lines, $5 \mathrm{~K}$ contour interval) and relative humidity (red and green lines represent 85 and $90 \%$, respectively) for the vertical cross section along Line $\mathrm{AB}$ (Fig. 5a) from the 5-km grid domain for 2000 LST 24 June 1987. The arrow indicates the approximate location of the Mei-Yu front. b Simulated winds for the vertical cross section along Line CD

(Fig. 5b). Contour interval is

$1 \mathrm{~m} \mathrm{~s}^{-1}$. c Same as $\mathbf{b}$ but for the NT run. d Same as b but for the S45 run

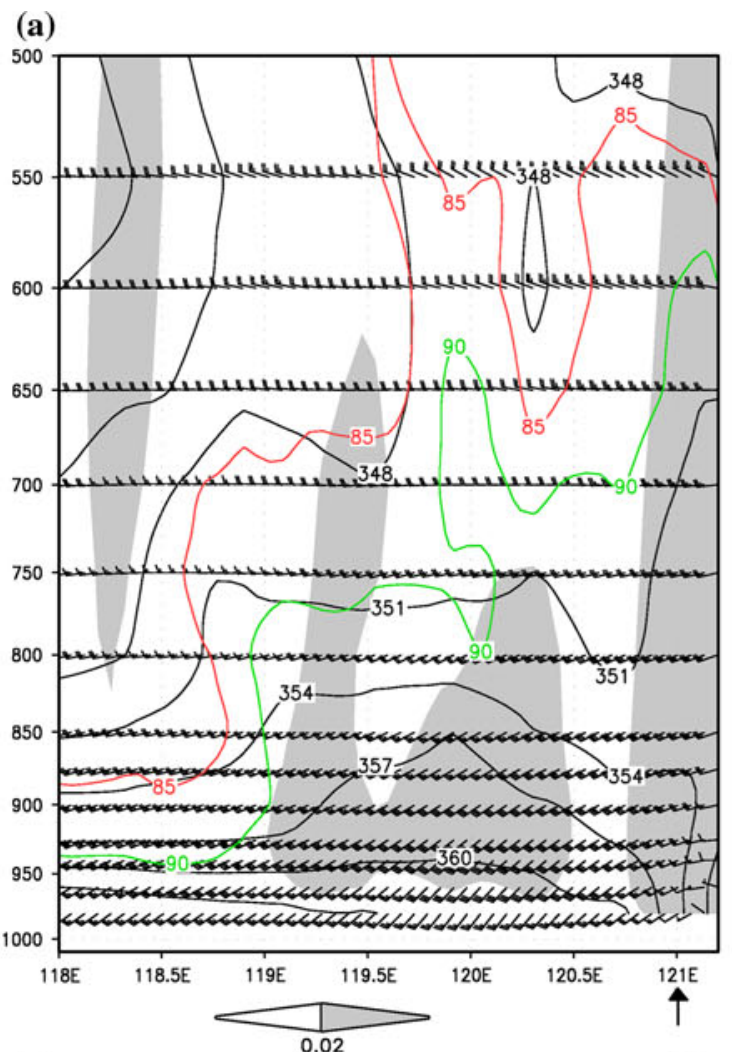

(b)

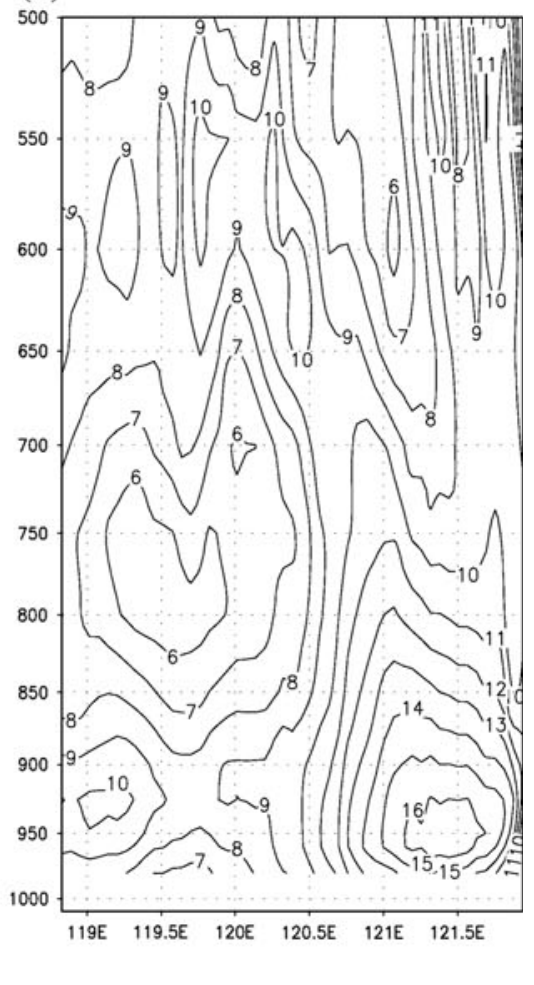

(c)

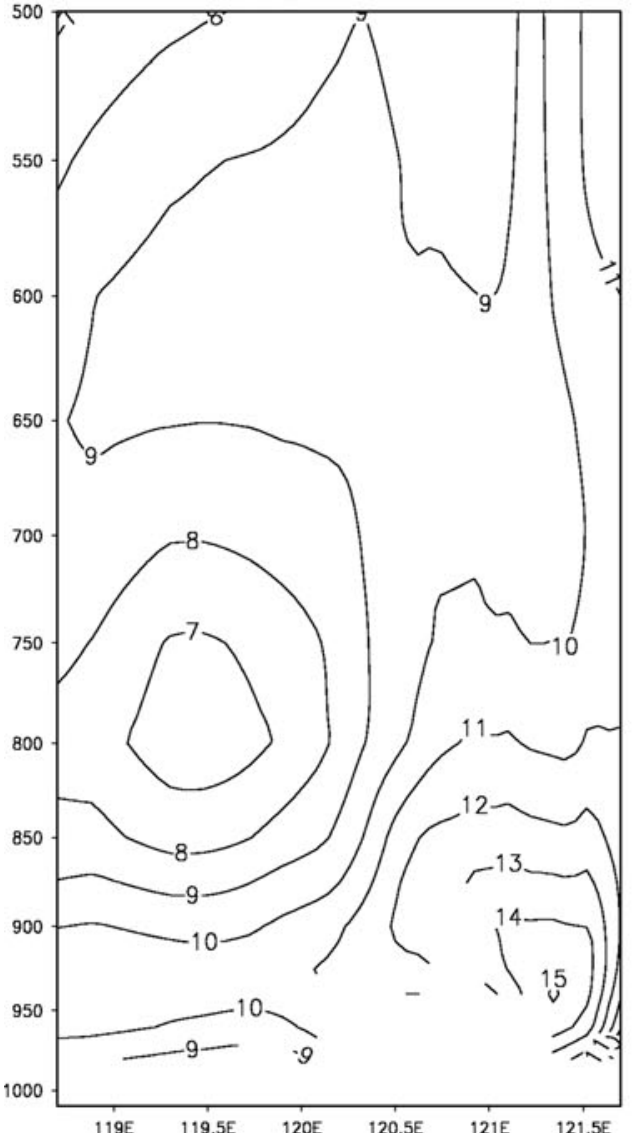

(d)

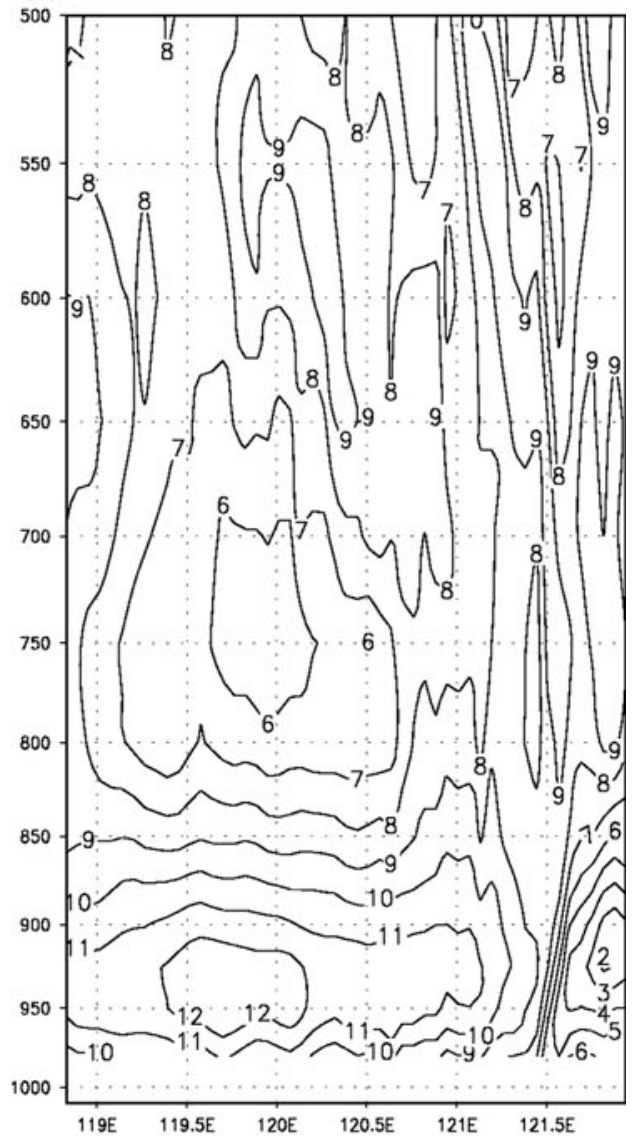




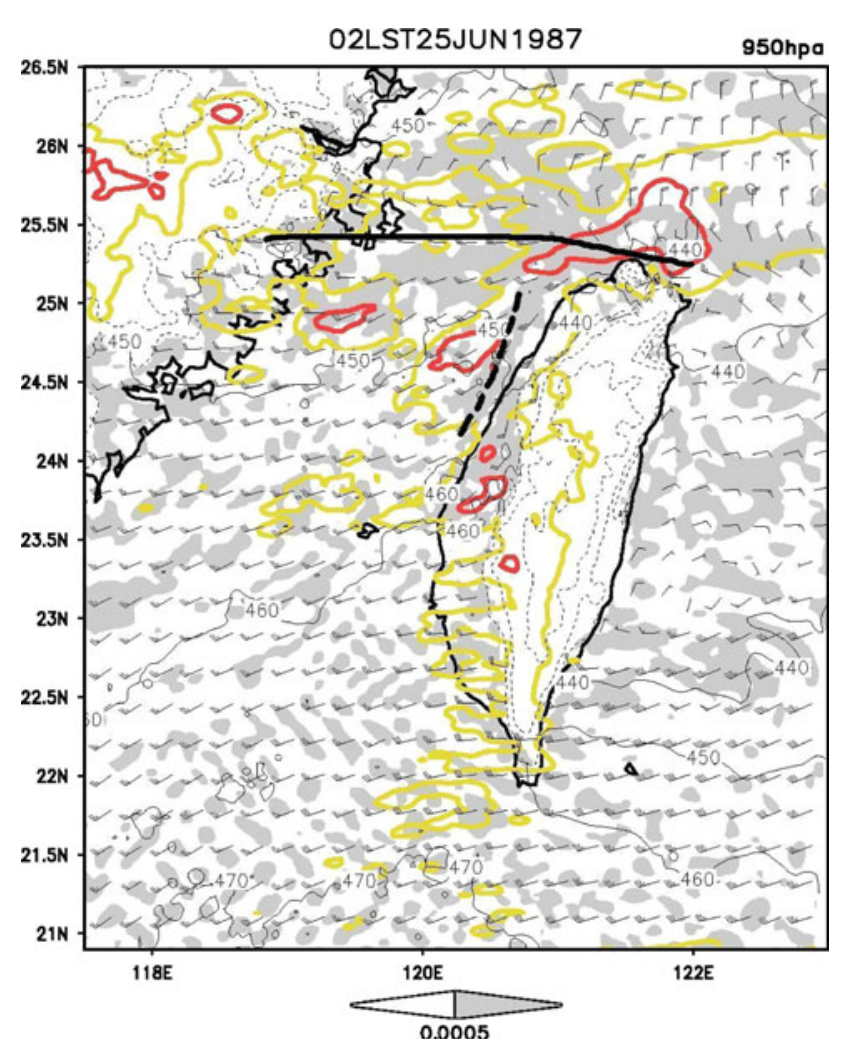

Fig. 7 Simulated geopotential height (solid lines, 10 gpm contour interval), horizontal winds (full barb, and half barb represent 5 and $2.5 \mathrm{~m} \mathrm{~s}^{-1}$, respectively) and convergence (shaded areas represent the convergence exceeding $0.0005 \mathrm{~s}^{-1}$ ) at the $950-\mathrm{hPa}$ level, and hourly rainfall amount [denoted by the yellow lines $(1 \mathrm{~mm})$ and red lines $(15 \mathrm{~mm})$ ] from the $5-\mathrm{km}$ grid domain for 0200 LST 25 June. The heavy solid line represents the approximate position of the Mei-Yu front determined from surface winds. The wind-shear line is shown by a heavy dashed line. The dotted lines denote terrain elevation at 200, 500 , and $1,500 \mathrm{~m}$, respectively

important factor for the occurrence of the barrier jet over northwestern Taiwan.

In order to estimate the relative contribution of the orographically induced pressure gradient force by Taiwan's topography and the synoptic-scale pressure gradient force, a sensitivity test without Taiwan's topography (the NT run, Table 1) is performed. The difference in the perturbation pressure between the southwestern and the northwestern coast in the CR run (Fig. 9c) is reduced to about $0.8 \mathrm{hPa}$ in the NT run (Fig. 10a). Therefore, for IOP 13 , an additional $50-60 \%(1 \mathrm{hPa}$ out of $1.8 \mathrm{hPa})$ of the meridional pressure gradient is orographically induced. The sensitivity test demonstrates that, as suggested by $\mathrm{Li}$ and Chen (1998), the orographically induced meridional perturbation pressure gradient plays an important role in the acceleration of the southerly wind component leading to the generation of the barrier jet off the northwestern coast of Taiwan.
4.3 The impact of Taiwan topography on localized heavy rainfall

To test our hypothesis that for this case, without significant orographic blocking in the early morning, the low-level convergence associated with the synoptic flow may not be adequate to initiate the rainband offshore leading to the coastal precipitation over northwestern Taiwan, the simulated low-level airflow and rainfall distribution from the $\mathrm{CR}$ and NT runs are compared. In the $5-\mathrm{km}$ grid simulation of the NT run, valid at 2000 LST 24 June, the simulated short-wave trough at the 850 -hPa level (Fig. 11a) is over the northern Taiwan Strait as compared with over the southeastern coast of China in the control run (CR, Fig. 5a). A westerly flow is simulated over the northern Taiwan Strait and northern Taiwan without a strong southwesterly flow along the northwestern coast (or the barrier jet) as compared with the CR run (Fig. 5a). Similar to the CR run, the simulated Mei-Yu front is to the north of Taiwan with rainfall extending from the ocean to the southeastern China coast. Along the cross section CD (Fig. 5b), no strong southwesterly flow appears over the northwestern Taiwan coast $\left(\sim 120^{\circ} \mathrm{E}\right.$ to $\left.\sim 121^{\circ} \mathrm{E}\right)$ (Fig. 6c), in contrast to the simulated barrier jet in the CR run (Fig. 6b). At 0200 LST 25 June, the simulated Mei-Yu front (Fig. 11b), moving faster than the one found in the control run (Fig. 7), reaches northern Taiwan. The NE-SW oriented prefrontal rainband and the barrier jet at the 950-hPa level in the CR run are not simulated in the NT run. Instead, most simulated rainfall over the coastal area is oriented in an east-west direction along the Mei-Yu front in the NT run.

The simulated rainfall accumulation during 0000-2000 LST 25 June from the $1.67-\mathrm{km}$ grid simulation in the NT run (Fig. 8b) is mainly over northern and central Taiwan and the Taiwan Strait. The observed northeast-southwest oriented rainfall axis is simulated in Fig. 8 as compared with the CR run (Fig. 8a). In the CR run, more than $150 \mathrm{~mm}$ of rainfall accumulation is simulated over the central Taiwan coast $\left(24.6^{\circ} \mathrm{N}\right)$ (Fig. 8a). It is apparent that the synoptic-scale forcing by the Mei-Yu front/jet system alone is inadequate to initiate the offshore rainband within the Taiwan Strait and the subsequent occurrence of the coastal heavy rainfall event.

\subsection{Impact of the diurnal heating cycle on the strength of the barrier jet}

The CR12 run is designed to investigate the impact of the diurnal heating cycle on orographic blocking and the strength of the barrier jet (Table 1). The winds at 1400 LST in the CR run (Fig. 12a) indicate the presence of onshore flow over the southwestern coast, in response to solar 

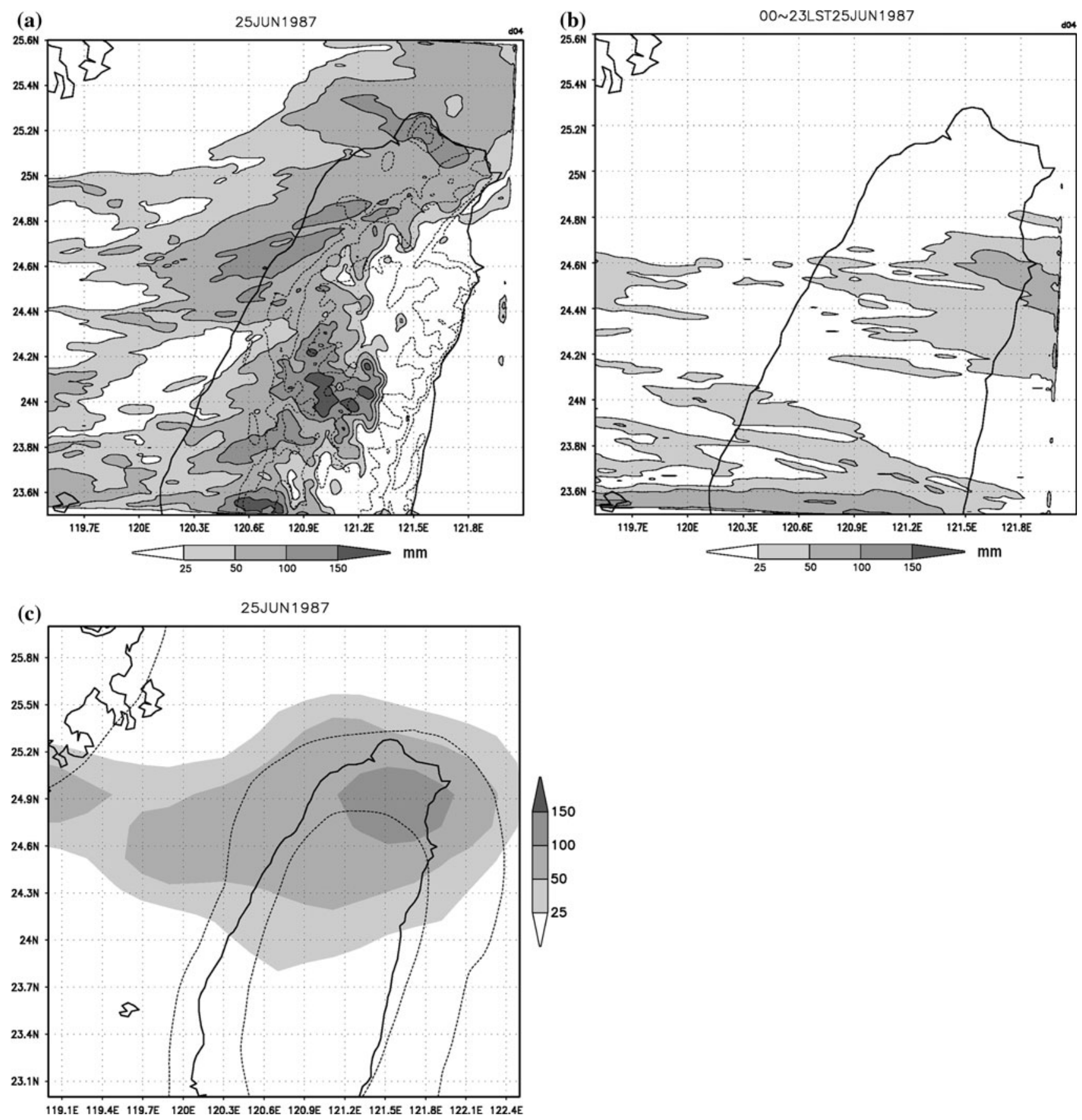

Fig. 8 a Simulated daily rainfall accumulation (shown by the gray scale in $\mathrm{mm}$ ) from the CR run from the $1.67-\mathrm{km}$ grid domain for 25 June 1987. The dotted lines denote terrain elevation at 200, 500, and $1,500 \mathrm{~m}$, respectively. (b) Same as a but for the NT run. c Simulated

daily rainfall accumulation (shown by the gray scale in $\mathrm{mm}$ ) from the S45 run for 25 June 1987. The dotted lines denote terrain elevation at 50 and $500 \mathrm{~m}$, respectively. The coast lines of China and Taiwan are delineated as solid lines

heating under prevailing southwesterly monsoon flow. Furthermore, along the east-west cross section L1 passing through southwestern Taiwan (Fig. 12a), a well-mixed layer develops over land in the afternoon hours (Fig. 13a). In contrast, at 0200 LST from the CR12 run, with nocturnal cooling, the low-level air over southwestern Taiwan is stably stratified (Fig. 13b). Note that the CR run at 1400

LST and the CR12 run at 0200 LST are driven by the same initial conditions and lateral forcing after $6 \mathrm{~h}$ of model integration.

At the surface, the flow over southwesterly Taiwan has an upslope-wind component at 1400 LST (Fig. 12a) as compared with the downslope-wind component at the foothills of southern Taiwan at 0200 LST in the CR12 run 
Fig. 9 a Simulated meridional winds for 2000 LST 24 June from the $5-\mathrm{km}$ grid domain at $\sigma=0.933$. The contour interval is $2 \mathrm{~m} \mathrm{~s}^{-1}$. Lagrangian acceleration of meridional winds (including the local change and the advection terms) is represented by the color scale in $10^{-3} \mathrm{~m} \mathrm{~s}^{-2}$. b Simulated u-component winds for 2000 LST 24 June from the 5-km grid domain at $\sigma=0.933$ in the $\mathrm{CR}$ experiment. The contour interval is $2 \mathrm{~m} \mathrm{~s}^{-1}$. The brown areas represent the total horizontal wind speed greater than $15 \mathrm{~m} \mathrm{~s}^{-1}$. c Simulated meridional acceleration due to pressure gradient forces contributed by the pressure associated with a hydrostatically balanced reference state and a perturbation pressure deviated from this reference state for 2000 LST 24 June from the 5 -km grid domain at $\sigma=0.933$ in the CR experiment is shown by color scale in $10^{-3} \mathrm{~m} \mathrm{~s}^{-2}$. Simulated perturbation pressure at near the $950 \mathrm{hPa}$-level is given by solid lines (positive values) and dashed lines (negative values), respectively. The contour interval is $30 \mathrm{~Pa}$. d Same as in $\mathbf{c}$ but for the Coriolis force term. e Same as in $\mathbf{c}$ but for the mixing term (including the subgrid-scale eddy fluxes, numerical smoothing, and truncation errors). The color scale is in $10^{-6} \mathrm{~m} \mathrm{~s}^{-2}$
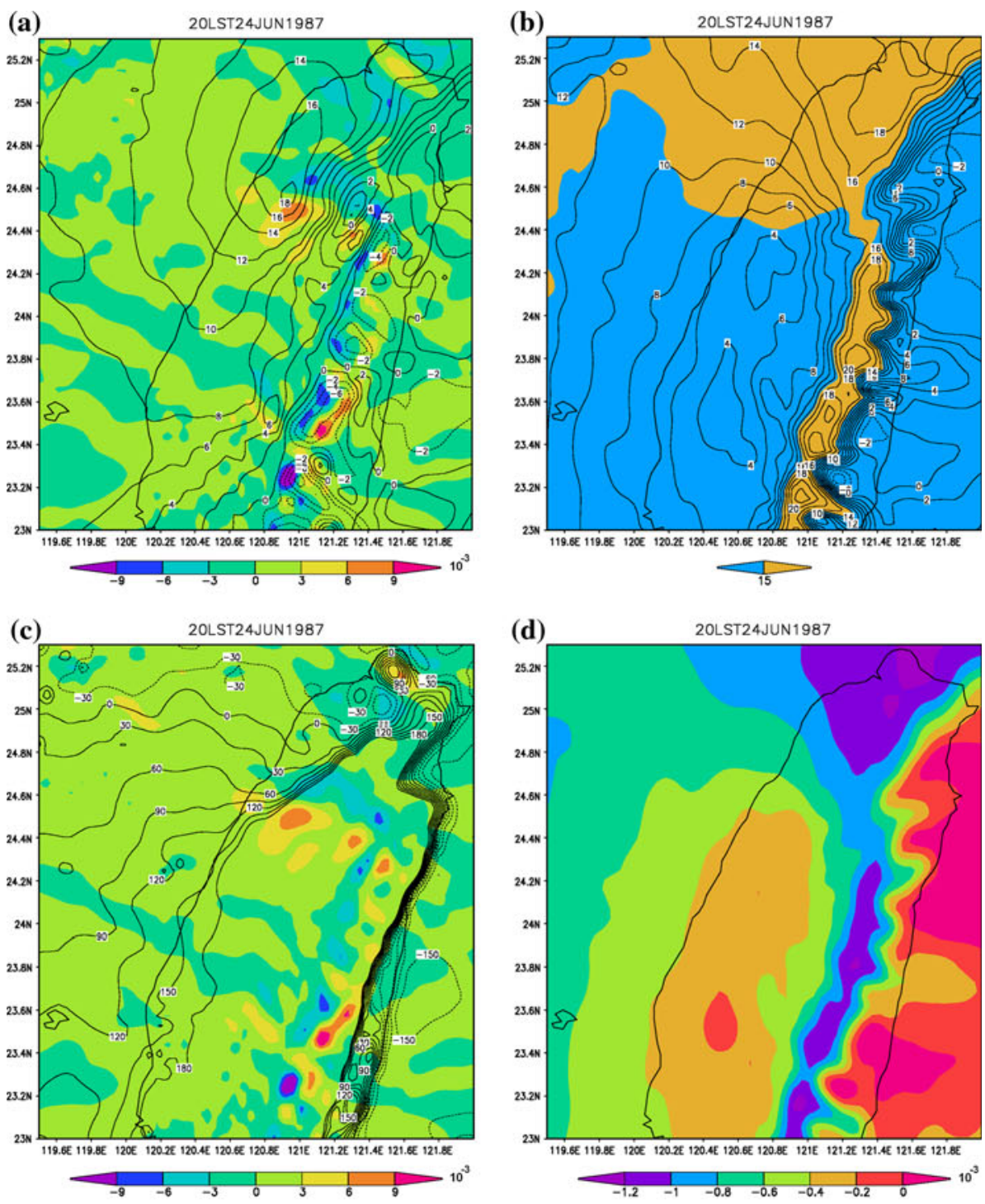

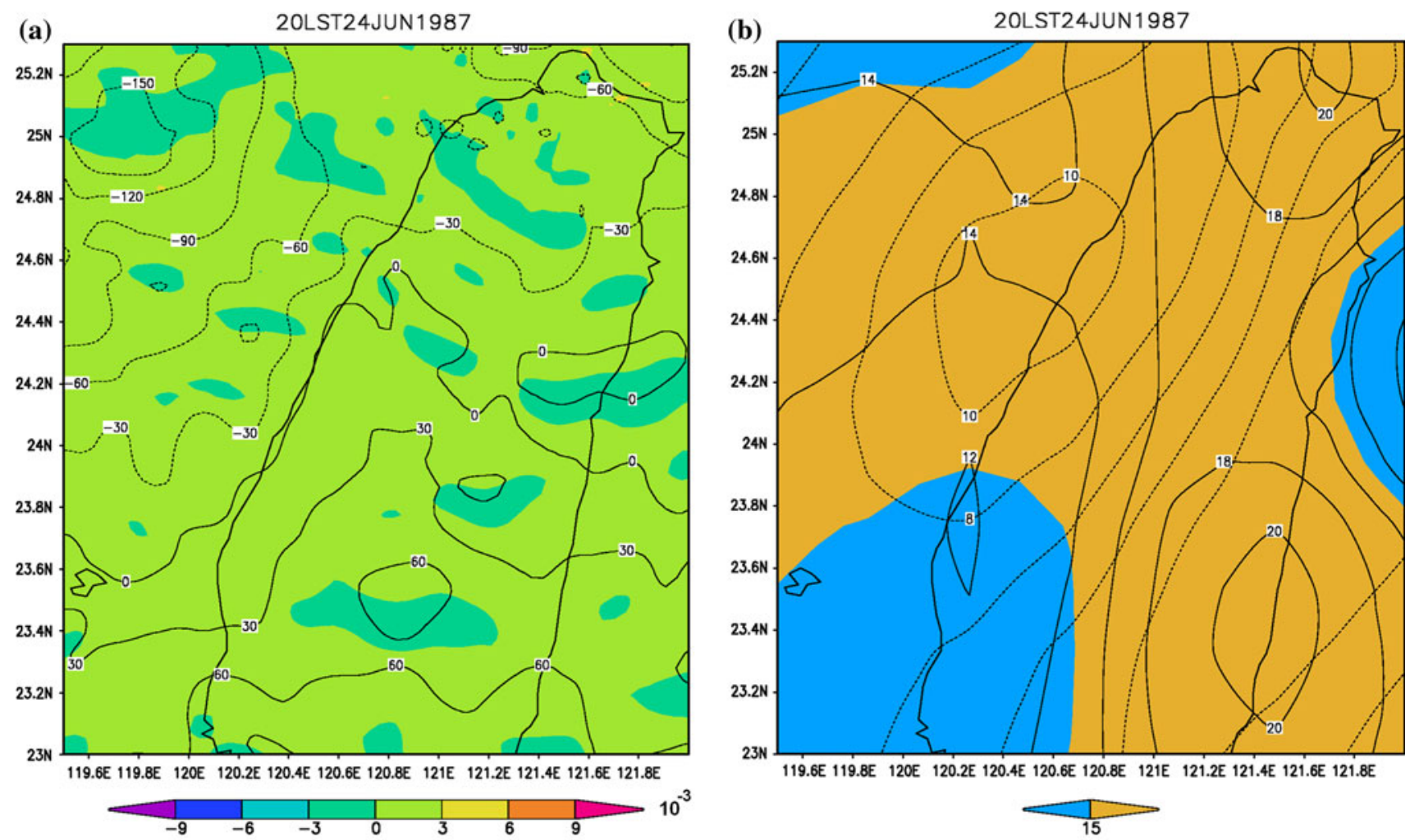

119.6E 119.8E $120 \mathrm{E} \quad 120.2 \mathrm{E} \quad 120.4 \mathrm{E} \quad 120.6 \mathrm{E} \quad 120.8 \mathrm{E} \quad 121 \mathrm{E} \quad 121.2 \mathrm{E} \quad 121.4 \mathrm{E} 121.6 \mathrm{E} \quad 121.8 \mathrm{E}$

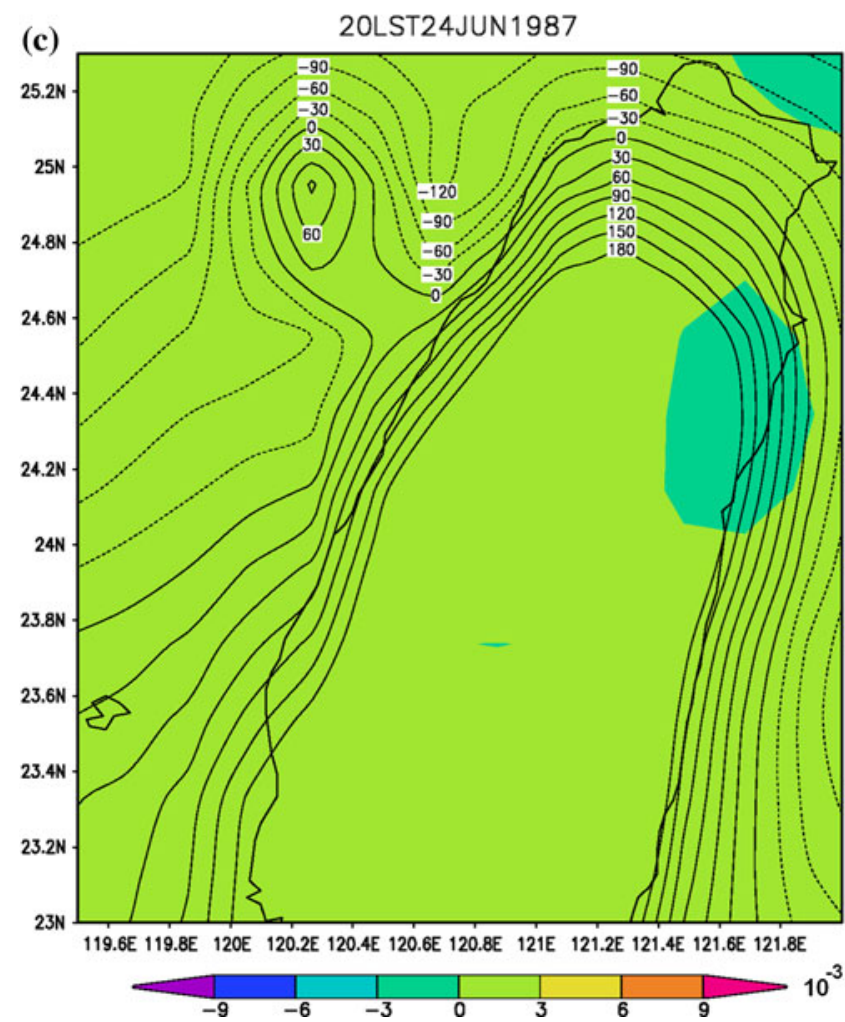

Fig. 10 a Same as Fig. 9c but for the NT experiment. b Simulated $\mathrm{u}$-component (solid lines) and meridional winds (dotted lines) in the

$2 \mathrm{~m} \mathrm{~s}^{-1}$. The brown areas represent the total horizontal wind speed greater than $15 \mathrm{~m} \mathrm{~s}^{-1}$. c Same as Fig. 9c but for the S45 experiment 


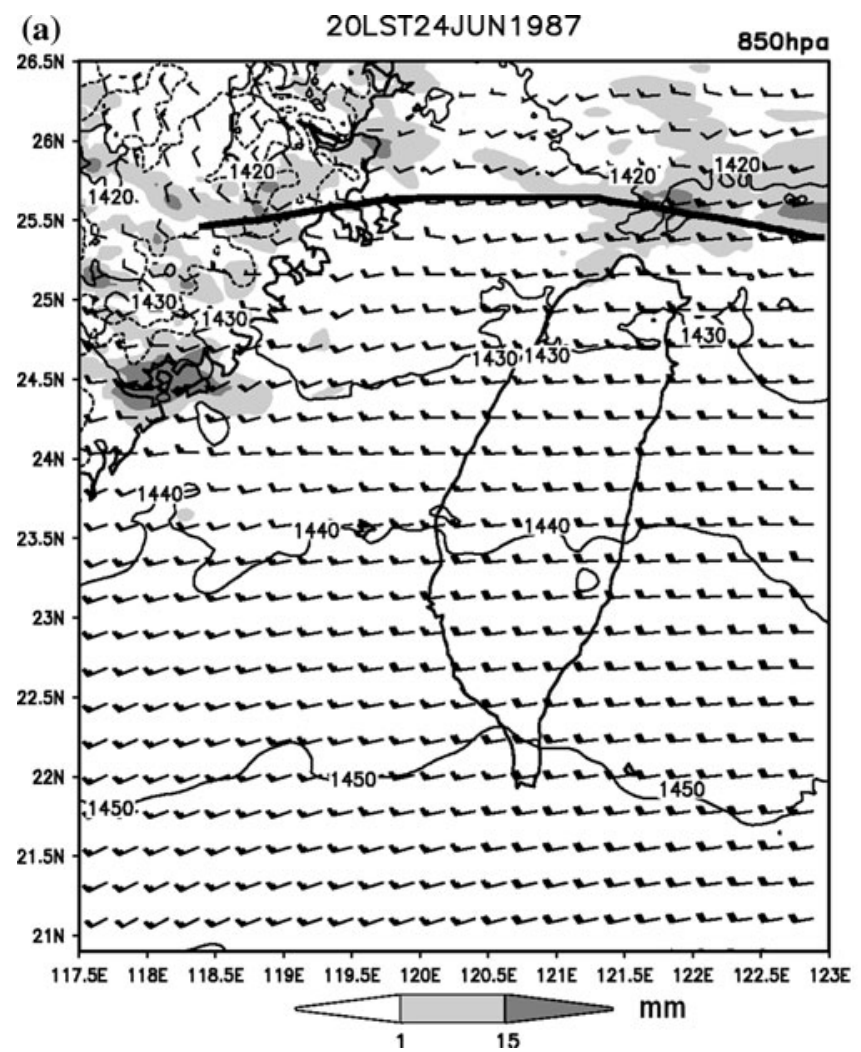

Fig. 11 a Simulated geopotential height (solid lines, 10 gpm contour interval), horizontal winds (full barb, and half barb represent 5 and $2.5 \mathrm{~m} \mathrm{~s}^{-1}$, respectively) at the $850-\mathrm{hPa}$ level, and hourly rainfall amount (denoted by the gray scale in $\mathrm{mm}$ ) from the $5-\mathrm{km}$ grid domain

(Fig. 12c). Upstream flow splitting off the southwestern coast at 1400 LST in the CR run (Fig. 12a) is less significant as compared with 0200 LST in the CR12 run (Fig. 12c), with a lower minimum surface pressure associated with the mesolow off the southeastern Taiwan coast (998 $\mathrm{hPa}$ vs. 1,000 hPa). It is apparent that, with the simulated differences in stability over land related to the diurnal heating cycle, orographic blocking is more significant at night than during the day in the model in agreement with the analysis of surface wind and pressure patterns presented by Chen and Li (1995b). The meridional winds over western and northwestern coasts along the cross section CD in Fig. 5b indicate that flow acceleration downstream along the coast is more significant at 0200 LST in the CR12 run increasing from 5 to $17 \mathrm{~m} \mathrm{~s}^{-1}$ (Fig. 14a) as compared with 6 to $14 \mathrm{~m} \mathrm{~s}^{-1}$ at 1400 LST in the CR run (Fig. 14b), leading to enhanced low-level convergence off the northwestern Taiwan coast (Fig. 12a, c). The meridional perturbation pressure difference near the coastal area between 23.5 and $25^{\circ} \mathrm{N}$ at $1400 \mathrm{LST}$ in the $\mathrm{CR}$ run (Fig. 12b) is about $1 \mathrm{hPa}$ weaker than that at $0200 \mathrm{LST}$ in the CR12 run (Fig. 12d). It is evident that the simulated barrier jet at $0200 \mathrm{LST}$ in the CR12 run is stronger than at

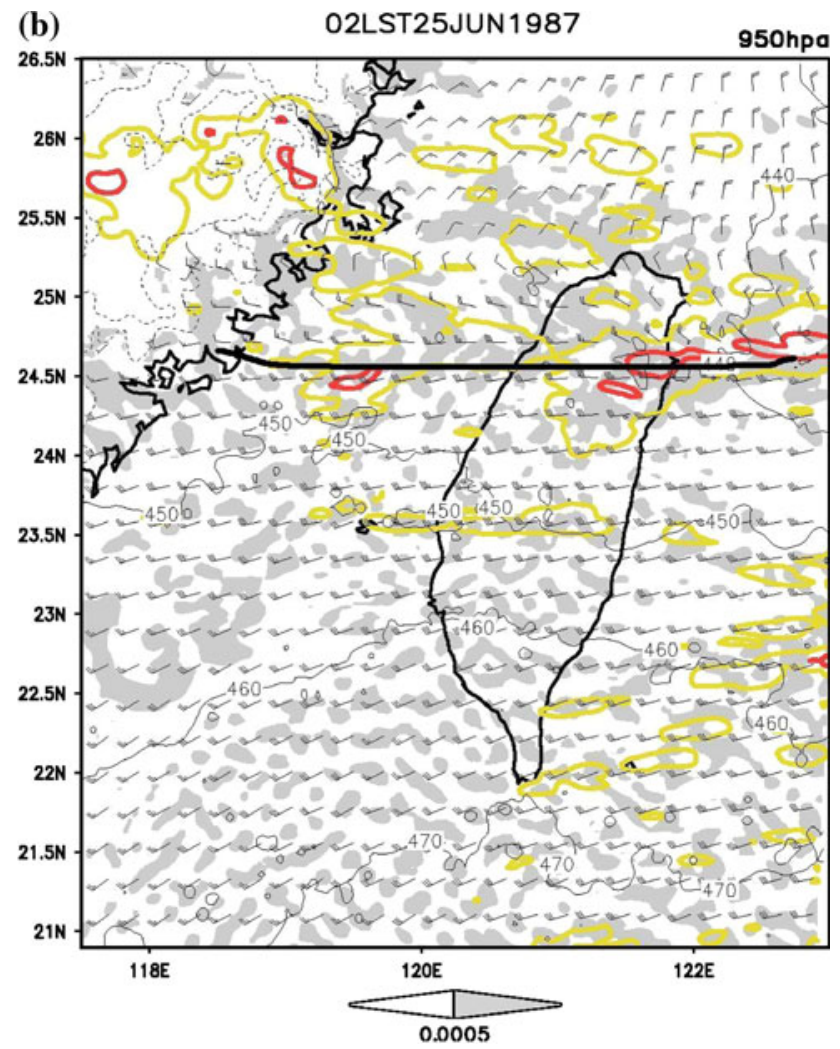

of the NT run for 2000 LST 24 June. The heavy solid line represents the approximate position of the Mei-Yu front. b Same as Fig. 7 but for the NT run

1400 LST in the CR run due to the simulated differences in stability over land in response to the diurnal heating cycle.

\subsection{The impact of model grid spacing on the strength of the barrier jet}

The strength of the barrier jet in the S45 run (Fig. 6d) is slightly weaker than in the CR run (Fig. 6b). The average mountain height in the S45 run is around $1 \mathrm{~km}$, which is about $2 \mathrm{~km}$ lower than in the CR run. Thus, the upstream $\mathrm{Fr}$ increases from $0.3-0.5$ to $0.6-1$ in the $\$ 45$ run. As a result, the orographic blocking in the S45 run is not as significant as in the CR run. The simulated meridional acceleration along the coast due to the pressure gradient force is less significant in the S45 run (Fig. 10c) than in the CR run (Fig. 9c). The differences in the perturbation pressure between the southwestern coast $\left(\sim 120^{\circ} \mathrm{E}\right.$ and $\left.23.5^{\circ} \mathrm{N}\right)$ and the northwestern coast $\left(\sim 121^{\circ} \mathrm{E}\right.$ and $\left.24.9^{\circ} \mathrm{N}\right)$ in the $\mathrm{S} 45$ run is about $1.2 \mathrm{hPa}$ (Fig. 10c), which is about $0.6 \mathrm{hPa}$ less than in the CR run (Fig. 9c). As a result, the speed of the meridional wind over the northwestern coast of Taiwan in the S45 run (Fig. 10b) is weaker than in the CR run (Fig. 9a). With less significant orographic blocking, the 

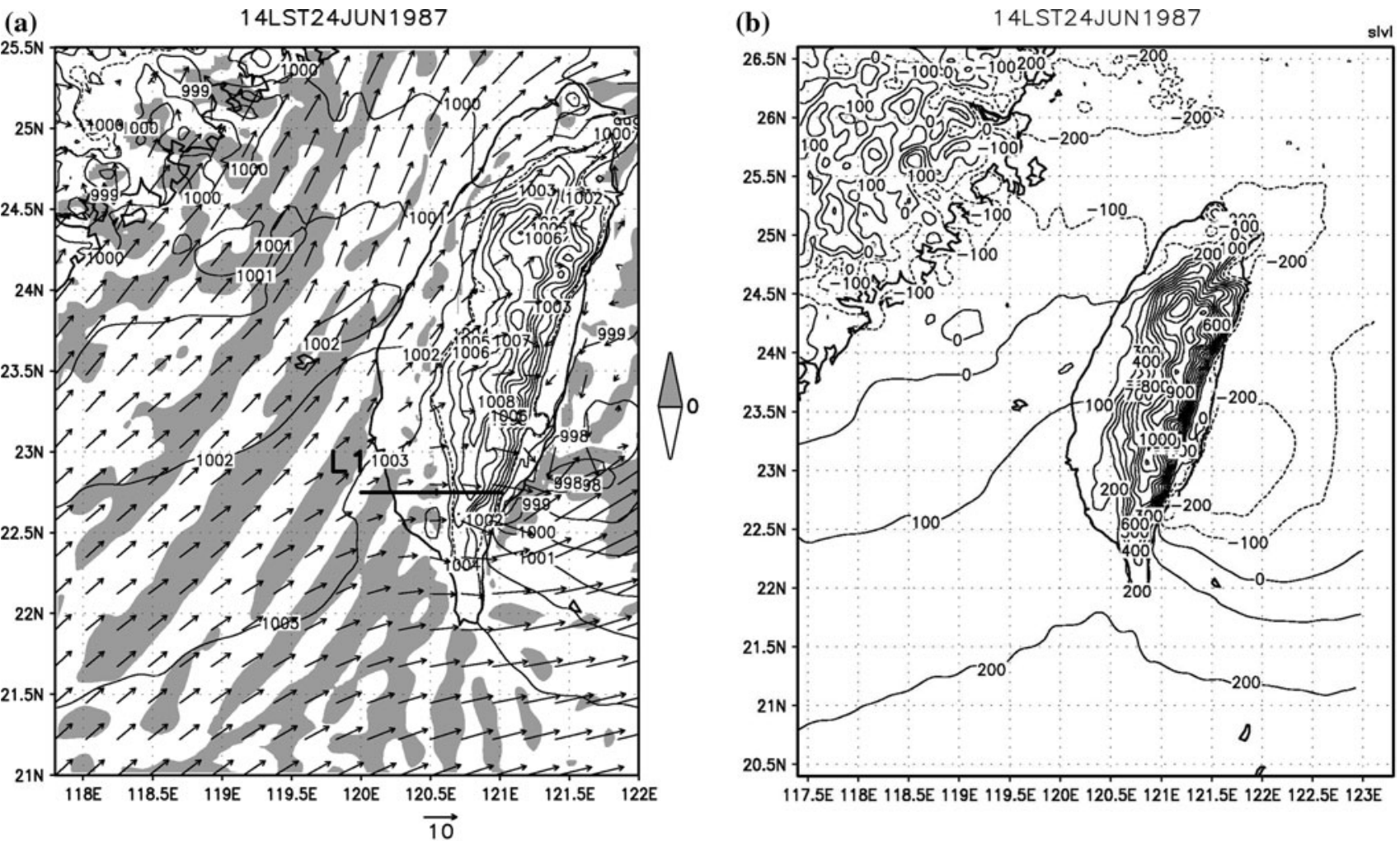

(c) O2LST24JUN1987
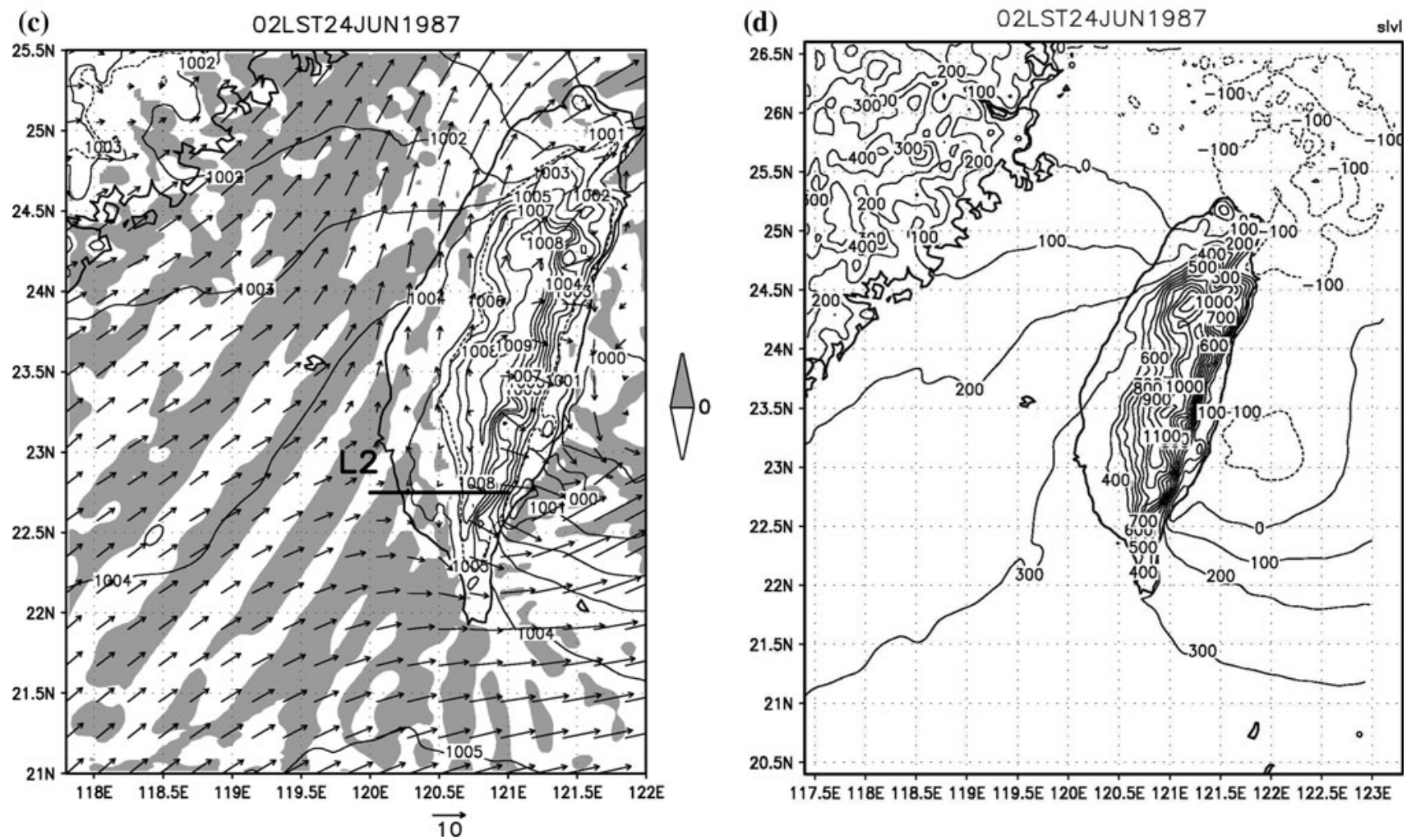

Fig. 12 a Simulated surface winds (the magnitude of $10 \mathrm{~m} \mathrm{~s}^{-1}$ is shown at the bottom of the figure) and pressure (solid lines) from the CR run for 1400 LST 24 June. The contour interval for pressure is $1 \mathrm{hPa}$. The shaded areas denote the convergence at $960 \mathrm{hPa}$-level. The 500-m terrain contour (dotted line) is superimposed. b Simulated

surface perturbation pressure (solid and dashed lines denote positive and negative values, respectively) from the CR run for 1400 LST 24 June. The contour interval is $100 \mathrm{~Pa}$. c Same as a but for 0200 LST 24 June from the CR12 run. d Same as b but for 0200 LST 24 June from the $\mathrm{CR} 12$ run 
(a)

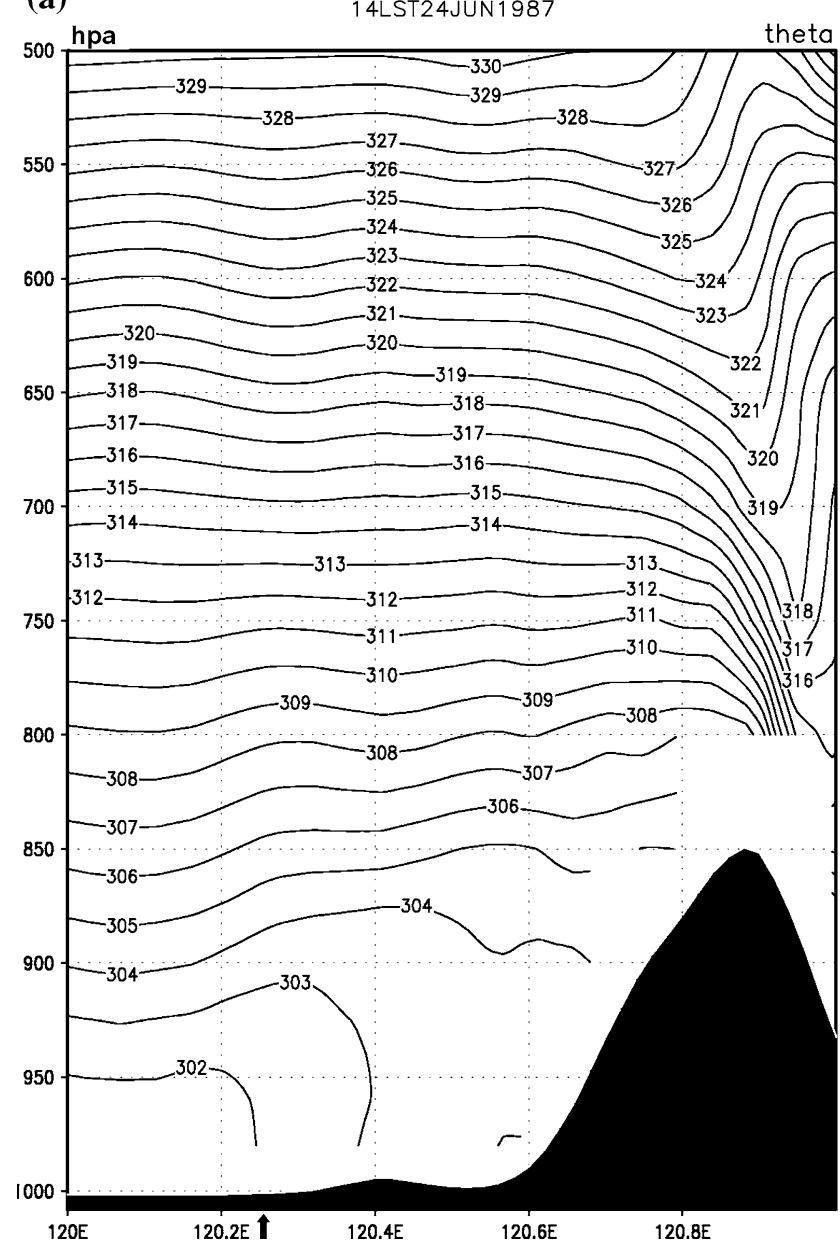

Fig. 13 a Simulated potential temperature for the vertical cross section along L1 (Fig. 12a) from the CR run for 1400 LST 24 June. The contour interval is $1 \mathrm{~K}$. The smooth terrain is given at the bottom

zonal wind is stronger in the S45 run (Fig. 10b) than in the CR run (Fig. 9b). With a stronger zonal-wind component and a weaker meridional-wind component as compared with those in the CR run, the total wind speed of the barrier jet in the S45 run (Fig. 6d) is only slightly less than in the $\mathrm{CR}$ run (Fig. 6b). Although the simulated rainfall accumulation from the S45 run on 25 June over northern Taiwan is over $100 \mathrm{~mm}$ (Fig. 8c), it fails to reproduce the observed rainband off the northwestern coast of Taiwan (Fig. 1). In addition, the simulated coastal rainfall accumulation in the $\mathrm{S} 45$ run is only $\sim 75 \mathrm{~mm}$, significantly less than in the CR run.

\section{Conclusion}

The WRF model is employed to study an unusual heavy coastal rainfall event over northwestern and central Taiwan. It occurred during 24-25 June 1987. The model is (b)

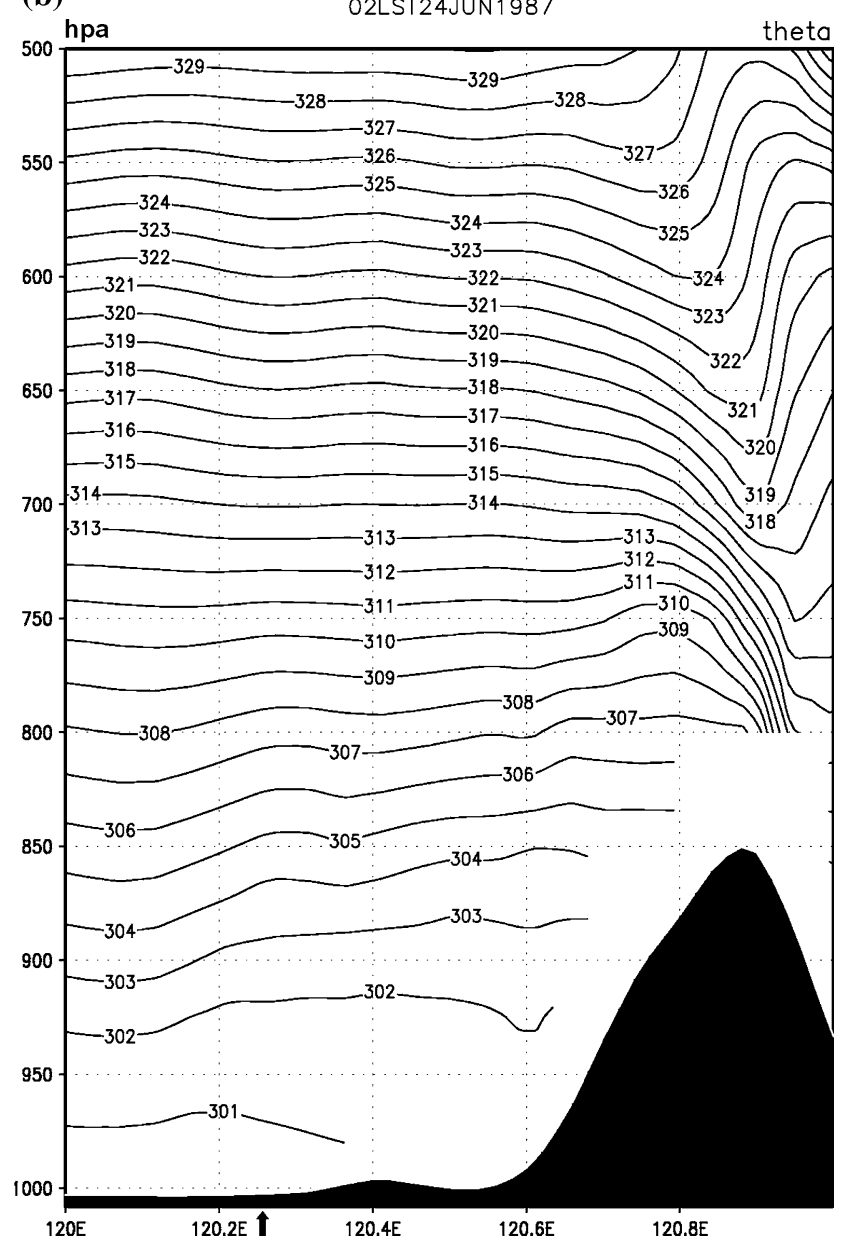

of the figure. The approximate location of the coastal line is shown by an arrow. b Same as a but along L2 in Fig. 12c for 0200 LST 24 June from the CR12 run

used to investigate the role of synoptic forcing, orographic effects, and the diurnal heating cycle on the generation of a prefrontal localized low-level convergence zone offshore leading to the observed coastal rainfall maximum.

This case is well simulated by the control experiment initialized at 0000 UTC (0800 LST) 24 June 1987 using the European Centre for Medium-Range Weather Forecasts data. A model sensitivity test without Taiwan terrain fails to reproduce the observed coastal rainfall maximum. The generation of the localized low-level convergence is closely related to the simulated strong winds with a large southwesterly wind component (or the barrier jet) along the northwestern coast as the surface front approaches. The simulated barrier jet is mainly produced by the additional $50-60 \%$ orographically induced meridional perturbation pressure gradient due to Taiwan's topography superimposed on the synoptic-scale pressure gradient force.

In the experiment without Taiwan's topography, neither the barrier jet nor the offshore rainband is simulated off the 
Fig. 14 a Simulated meridional winds for the vertical cross section along Line CD (Fig. 5b) from the CR12 run for 0200 LST 24 June. The contour interval is $1 \mathrm{~m} \mathrm{~s}^{-1}$. b Same as Fig. a but for 1400 LST 24 June from the $\mathrm{CR}$ run

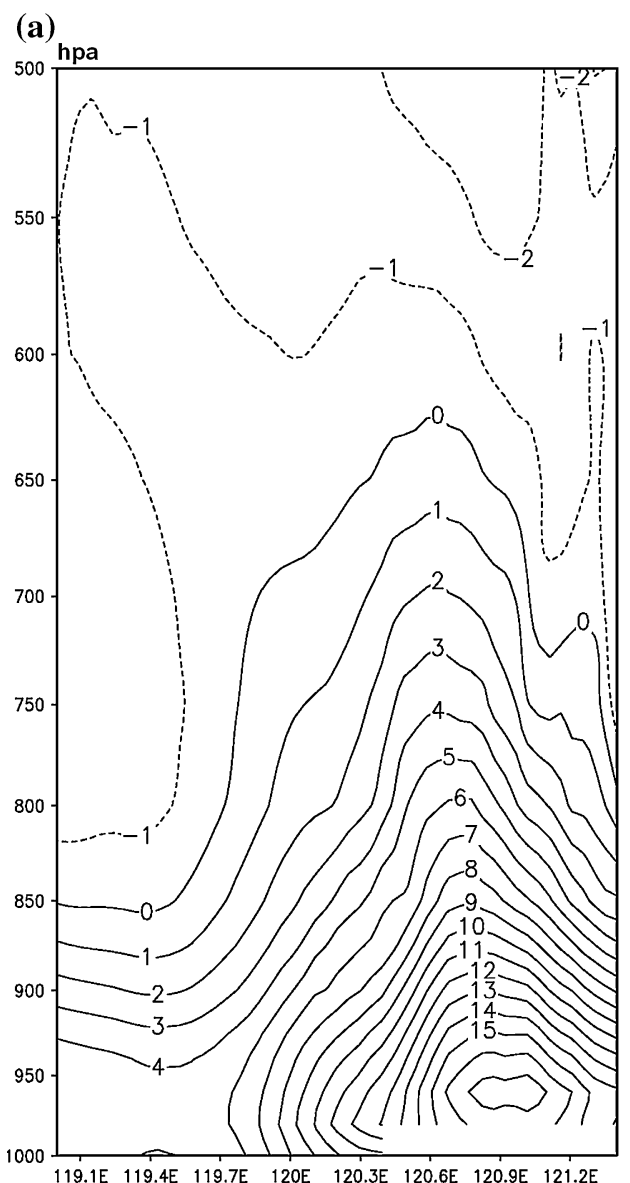

(b)

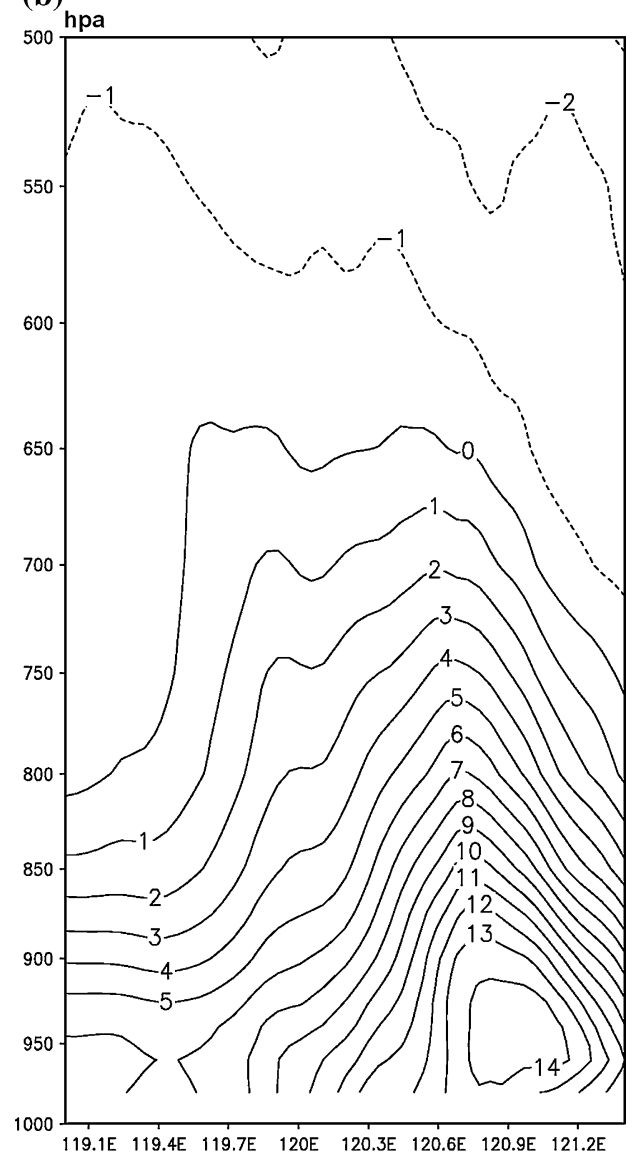

northwestern coast of Taiwan. Furthermore, the simulated rainfall is orientated in an east-west direction mainly associated with the passage of the Mei-Yu front. Over the coastal area from northwestern to central Taiwan, the simulated rainfall amount is lower than in the control run. It is apparent that for this case, synoptic forcing by the $\mathrm{Mei}-\mathrm{Yu}$ jet/front system is inadequate to initiate deep convection leading to the development of coastal heavy precipitation.

The diurnal heating cycle also impacts the strength of the simulated barrier jet over the northwestern Taiwan coast. The simulated barrier jet is stronger $\left(\sim 3 \mathrm{~m} \mathrm{~s}^{-1}\right)$ in the early morning than in the afternoon as orographic blocking is most significant when the surface air is the coldest.

The representation of the terrain in the model also impacts the simulated barrier jet and coastal rainfall. With a coarse horizontal resolution $(45 \mathrm{~km})$, the model terrain is smoother and lower $(\sim 2 \mathrm{~km})$ than in the control run, resulting in weaker orographic blocking. Accordingly, the strength of the simulated barrier jet is reduced in a lower resolution model compared with the control run with a weaker meridional wind component and a stronger zonal wind component. The simulated rainfall in the coarse resolution fails to produce the observed offshore rainband off the northwestern Taiwan coast. Thus, to successfully simulate this type of event, high-resolution mesoscale models adequately depicting Taiwan's terrain are required.

Acknowledgments This work was supported by the National Science Council, Taiwan, under Grants NSC 95-2111-M-008-036-AP1 and NSC 98-2111-M-008-017. The computer resources were supplied by the Center for Computational Geophysics, National Central University, Chung-Li, Taiwan. The authors thank D. Hitzl for editing the text.

Open Access This article is distributed under the terms of the Creative Commons Attribution Noncommercial License which permits any noncommercial use, distribution, and reproduction in any medium, provided the original author(s) and source are credited.

\section{Appendix}

$\frac{\partial V}{\partial t}=\mathrm{ADV}+\mathrm{PGF}+F_{\mathrm{V}}+F_{\mathrm{M}}$

where

$V=\mu_{\mathrm{d}} v / m, \mu_{\mathrm{d}}=\left(p_{\mathrm{dhs}}-p_{\mathrm{dht}}\right)$,

$m$ is the map scale factor. 
$p_{\mathrm{dhs}}$ and $p_{\mathrm{dht}}$ represent the hydrostatic pressure of the dry atmosphere at the surface and the hydrostatic pressure at the top of the dry atmosphere, respectively.

$\operatorname{ADV}($ the advection term $)=-\left\{m\left[\frac{\partial(u v)}{\partial x}+\frac{\partial(V v)}{\partial y}\right]+\frac{\partial \Omega v}{\partial \eta}\right\}$ where

$U=\mu_{\mathrm{d}} u / m, \eta=\left(p_{\mathrm{dh}}-p_{\mathrm{dht}}\right) / \mu_{\mathrm{d}}, \Omega=\mu_{\mathrm{d}} \dot{\eta} / m$

$p_{\mathrm{dh}}$ represents the hydrostatic pressure of the dry atmosphere.

$u$ and $v$ are the covariant velocities in the two horizontal directions, respectively.

PGF (the pressure gradient force term) $=$ $-\left\{\left(\mu_{\mathrm{d}} \alpha \frac{\partial p^{\prime}}{\partial y}+\mu_{\mathrm{d}} \alpha \frac{\partial \bar{p}}{\partial y}\right)+\left(\alpha / \alpha_{\mathrm{d}}\right)\left(\mu_{\mathrm{d}} \frac{\partial^{\prime}}{\partial y}+\frac{\partial p^{\prime}}{\partial \eta} \frac{\partial \Phi}{\partial y}-\mu_{\mathrm{d}}^{\prime} \frac{\partial \Phi}{\partial y}\right)\right\}$

$p=\bar{p}(z)+p^{\prime}$.

$\Phi($ the geopotential $)=\bar{\Phi}(z)+\Phi^{\prime}$

$\alpha($ the inverse density $)=\bar{\alpha}(z)+\alpha^{\prime}$

$\mu_{\mathrm{d}}=\bar{\mu}_{\mathrm{d}}+\mu_{\mathrm{d}}^{\prime}$

A variable with a prime denotes the perturbation from a hydrostatically balanced reference state, which is a function of height only and denoted by an overbar.

$F_{\mathrm{v}}$ denotes the Coriolis term and $F_{\mathrm{M}}$ denotes the mixing term.

\section{References}

Chen Y-L, Chen X-A, Zhang Y-X (1994) A diagnostic study of the low-level jet during TAMEX IOP 5. Mon Wea Rev 122:2257-2284

Chen Y-L, Li J (1995a) Large-scale conditions favorable for the development of heavy rainfall during TAMEX IOP 3. Mon Wea Rev 123:2978-3002

Chen Y-L, Li J (1995b) Characteristics of surface airflow and rainfall frequencies over the island of Taiwan during TAMEX. Mon Wea Rev 123:695-716

Chen Y-L (2000) Effects of island induced airflow on rainfall distributions during the Mei-Yu season over Taiwan. In: Proc. workshop on numerical simulations of precipitation in Taiwan Area. 17-18 Feb, National Central University, Chung-Li, Taiwan, pp 5-11

Chen C-S, Chen Y-L (2003) The rainfall characteristic of Taiwan. Mon Wea Rev 131:1323-1341

Chen C-S, Chen W-C, Chen Y-L, Lin P-L, Lai H-C (2005) Investigation of orographic effects on two heavy rainfall events over southwestern Taiwan during the Mei-Yu season. Atmos Res 73:101-130

Chen C-S, Lu C-H, Chen W-C (2007a) Numerical experiments investigating the mechanisms of a heavy rainfall event over northeastern Taiwan and a mesovortex during TAMEX. Meteor Atmos Phys 95:155-177

Chen C-S, Chen Y-L, Liu C-L, Lin P-L, Chen W-C (2007b) Statistics of heavy rainfall occurrences in Taiwan. Wea Forecast 22:981-1002

Chen C-S, Lin Y-L, Peng W-C, Liu C-L (2010) Investigation of a heavy rainfall event over southwestern Taiwan associated with a subsynoptic cyclone during the 2003 Mei-Yu season. Atmos Res 95:235-254

Dudhia J (1989) Numerical study of convection observed during the winter monsoon experiment using a mesoscale two-dimensional model. J Atmos Sci 46:3077-3107

Dudhia J (1996) A multi-layer soil temperature model for MM5. Preprints, Sixth PSU/NCAR Mesoscale Model Users' Workshop, Boulder, Colorado, pp 49-50. [Available online at http://www.mmm.ucar.edu/mm5/mm5v2/whatisnewinv2.html]

Grell GA, Devenyi D (2002) A generalized approach to parameterizing convection combining ensemble and data assimilation techniques. Geophys Res Lett 29 (14), Article 1693

Hong S-Y, Lim JJ-O (2006) The WRF single-moment 6-class microphysics scheme (WSM6). J Korean Meteor Soc 42:129_ 151

Hong S-Y, Noh Y, Dudhia J (2006) A new vertical diffusion package with an explicit treatment of entrainment processes. Mon Wea Rev 134:2318-2341

Kerns BWJ, Chen Y-L, Chang M-Y (2010) The diurnal cycle of winds, rain, and clouds over Taiwan during the Mei-Yu, summer, and autumn rainfall regimes. Mon Wea Rev 138:497-516

Kuo Y-H, Chen GT-J (1990) The Taiwan Area Mesoscale Experiment(TAMEX): an overview. Bull Am Meteor Soc 71:488-503

Li J, Chen Y-L (1998) Barrier jets during TAMEX. Mon Wea Rev 126:959-971

Li J, Chen Y-L, Lee W-C (1997) Analysis of a heavy rainfall event during TAMEX. Mon Wea Rev 125:1060-1081

Lin Y-J, Pasken RW, Chang H-W (1992) The structure of a subtropical prefrontal convection rainband. Part I: mesoscale kinematic structure determined from dual-Doppler measurements. Mon Wea Rev 120:1816-1836

Mlawer EJ, Taubman SJ, Brown PD, Iacono MJ, Clough SA (1997) Radiative transfer for inhomogeneous atmosphere: RRTM, a validated correlated-K model for the long-wave. J Geophys Res 102(D14):16663-16682

Overland JE, Bond N (1993) The influence of coastal orography: The Yakutat storm. Mon Wea Rev 121:1388-1397

Skamarock WC, Klemp JB, Dudhia J, Gill D, Barker D, Wang W, Powers JG (2005) A description of the Advanced Research WRF Version 2. NCAR Technical Note NCAR/TN-468 + STR, 88 pp

Yeh H-C, Chen Y-L (1998) Characteristics of rainfall distributions over Taiwan during the Taiwan Area Mesoscale Experiment (TAMEX). J Appl Meteorol 37:1457-1469

Yeh H-C, Chen Y-L (2002) The role of offshore convergence on coastal rainfall during TAMEX IOP 3. Mon Wea Rev 130:2709-2730

Yeh H-C, Chen Y-L (2003) Numerical simulations of the barrier jet over northwestern Taiwan during the Mei-Yu season. Mon Wea Rev 131:2709-2730

Zhang Q-H, Lau K-H, Kuo Y-H, Chen S-J (2003) A numerical study of a mesoscale convective system over the Taiwan Strait. Mon Wea Rev 131:1150-1170 